RESEARCH

SERIES

NUMBER 93

December 2019

\section{THE PREVALENCE AND EFFECT ON HOURS WORKED OF THE MINIMUM WAGE IN IRELAND \\ A SECTORAL AND REGIONAL ANALYSIS}

SEAMUS MCGUINNESS, PAUL REDMOND AND JUDITH DELANEY

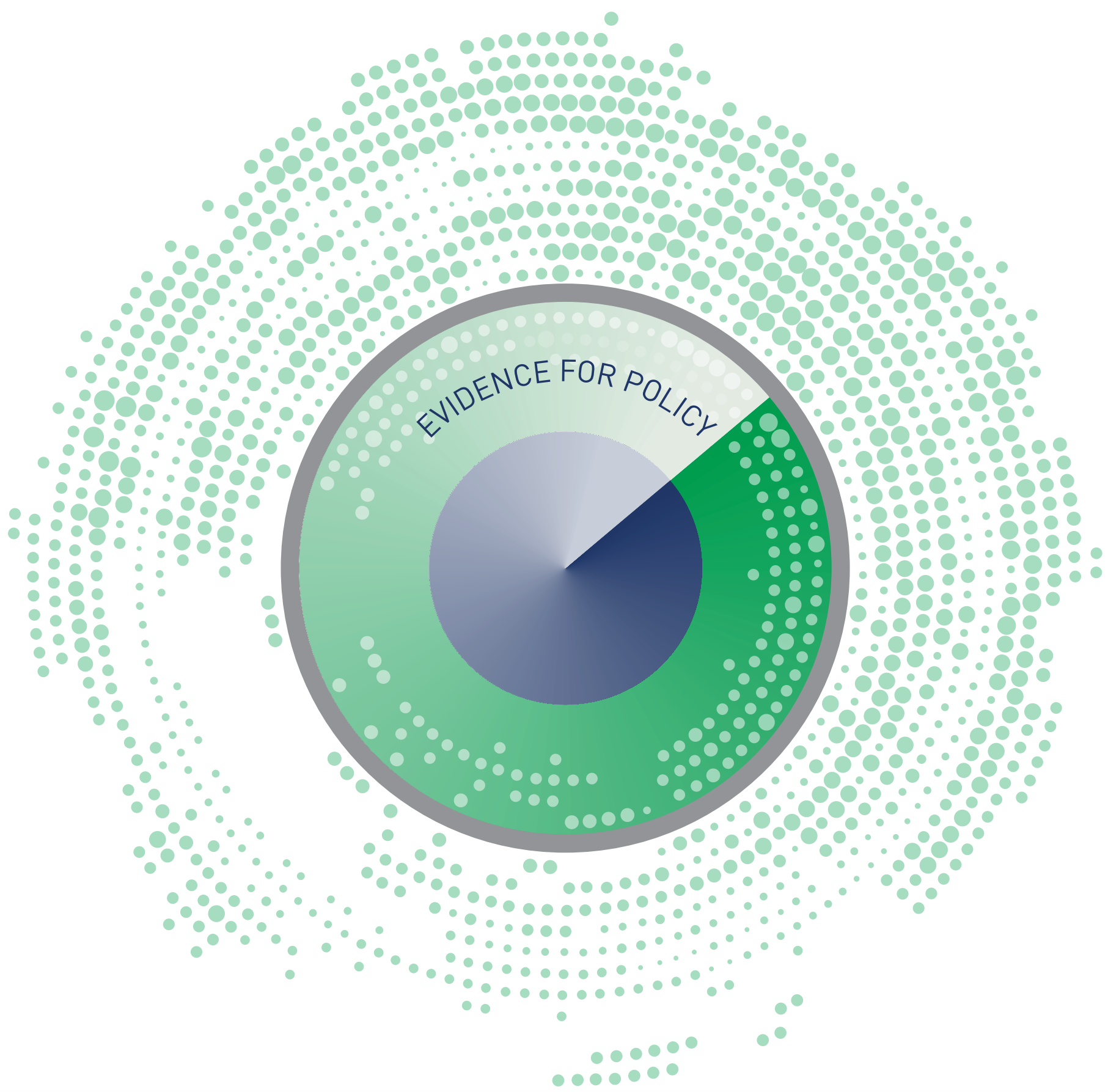




\title{
THE PREVALENCE AND EFFECT ON HOURS WORKED OF THE MINIMUM WAGE IN IRELAND: A SECTORAL AND REGIONAL ANALYSIS
}

\author{
Seamus McGuinness
}

Paul Redmond

Judith Delaney

September 2019

\section{RESEARCH SERIES}

\section{NUMBER 93}

Available to download from www.esri.ie

(C) The Economic and Social Research Institute

Whitaker Square, Sir John Rogerson's Quay, Dublin 2

ISBN 978-0-7070-0502-7

DOI https://doi.org/10.26504/rs93.pdf

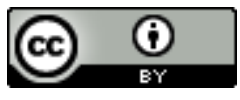

This Open Access work is licensed under a Creative Commons Attribution 4.0 International License (https://creativecommons.org/licenses/by/4.0/), which permits unrestricted use, distribution, and reproduction in any medium, provided the original work is properly credited. 


\section{ABOUT THE ESRI}

The mission of the Economic and Social Research Institute is to advance evidencebased policymaking that supports economic sustainability and social progress in Ireland. ESRI researchers apply the highest standards of academic excellence to challenges facing policymakers, focusing on 12 areas of critical importance to 21st Century Ireland.

The Institute was founded in 1960 by a group of senior civil servants led by Dr T.K. Whitaker, who identified the need for independent and in-depth research analysis to provide a robust evidence base for policymaking in Ireland.

Since then, the Institute has remained committed to independent research and its work is free of any expressed ideology or political position. The Institute publishes all research reaching the appropriate academic standard, irrespective of its findings or who funds the research.

The quality of its research output is guaranteed by a rigorous peer review process. ESRI researchers are experts in their fields and are committed to producing work that meets the highest academic standards and practices.

The work of the Institute is disseminated widely in books, journal articles and reports. ESRI publications are available to download, free of charge, from its website. Additionally, ESRI staff communicate research findings at regular conferences and seminars.

The ESRI is a company limited by guarantee, answerable to its members and governed by a Council, comprising 14 members who represent a cross-section of ESRI members from academia, civil services, state agencies, businesses and civil society. The Institute receives an annual grant-in-aid from the Department of Public Expenditure and Reform to support the scientific and public interest elements of the Institute's activities; the grant accounted for an average of 30 per cent of the Institute's income over the lifetime of the last Research Strategy. The remaining funding comes from research programmes supported by government departments and agencies, public bodies and competitive research programmes.

Further information is available at www.esri.ie 


\section{THE AUTHORS}

Seamus McGuinness is a Research Professor at the Economic and Social Research Institute (ESRI) and an Adjunct Professor at Trinity College Dublin (TCD). Paul Redmond is a Research Officer at the ESRI and an Adjunct Assistant Professor at TCD. Judith Delaney is a post-doctoral researcher at the Economic and Social Research Institute and Visiting Research Fellow at TCD.

\section{ACKNOWLEDGEMENTS}

The work carried out in this report was funded by the Low Pay Commission. We would like to thank Mary Mosse, Frank Walsh and all individuals within the Commission who provided assistance during the project and provided us with valuable comments on earlier drafts of the report. We would also like to thank the Central Statistics Office for access to the data used in the study.

This report has been accepted for publication by the Institute, which does not itself take institutional policy positions. All ESRI Research Series reports are peer reviewed prior to publication. The authors are solely responsible for the content and the views expressed. 



\section{TABLE OF CONTENTS}

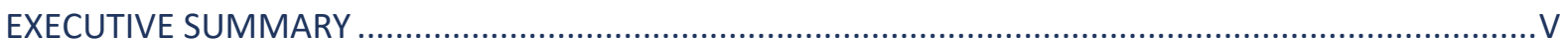

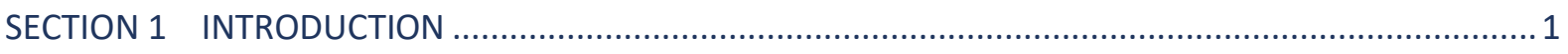

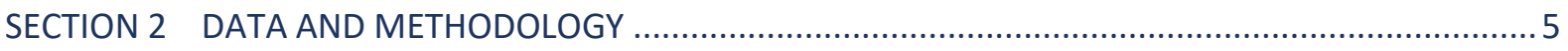

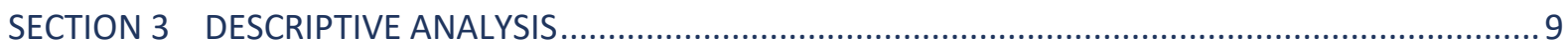

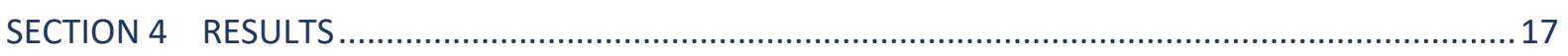

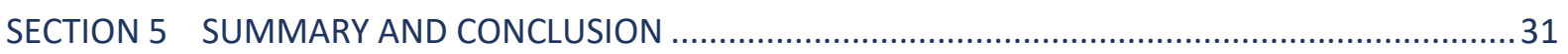

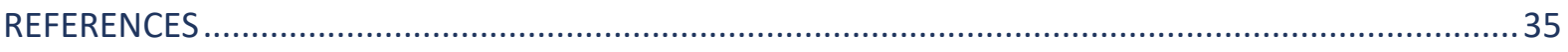

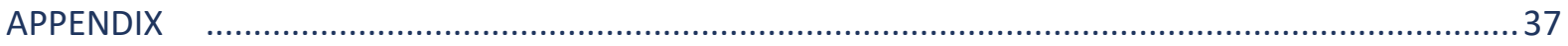

\section{LIST OF TABLES}

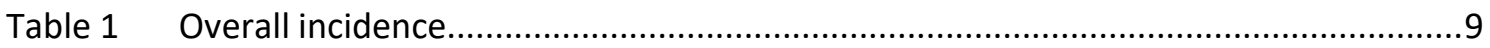

Table $2 \mathrm{a} \quad$ Overall incidence by region ......................................................................... 10

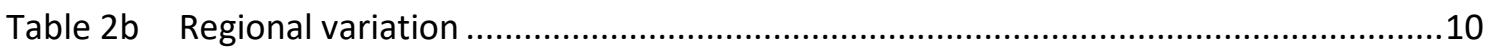

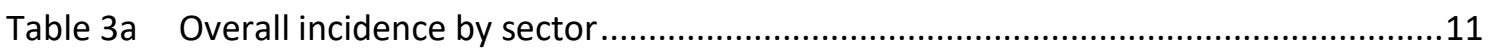

Table $3 b \quad$ Sectoral variation of minimum wage workers ................................................... 11

Table 4 Average characteristics of minimum wage workers by region in 2017 and $2018 \ldots . .12$

Table 5 Characteristics of minimum wage workers by sector in 2017 and $2018 \ldots \ldots \ldots \ldots \ldots . . . .14$

Table 6 Characteristics of treated and control by year ..............................................

Table 7 Difference-in-Differences estimates of the effect of minimum wage change on hours worked ........................................................................................ 18

Table 8 Difference-in-Differences estimates of the effect of minimum wage change on hours worked by sector

Table 9 Difference-in-Differences estimates of the effect of minimum wage change on hours worked by region of work

Table 10 Difference-in-Differences estimates of the effect of minimum wage change on hours worked by region of residence ...........................................................2 22

Table 11 Difference-in-Differences placebo estimates by sector.....................................24

Table 12 Difference-in-Differences placebo estimates by region .....................................25

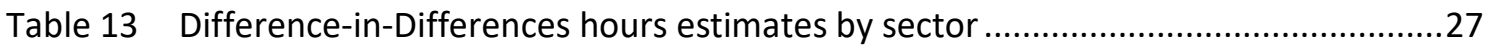


Table 14 Difference-in-Differences hours estimates by region .28

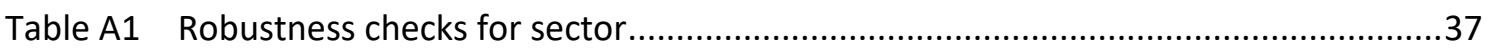

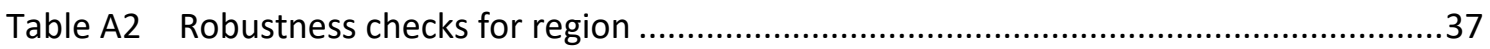

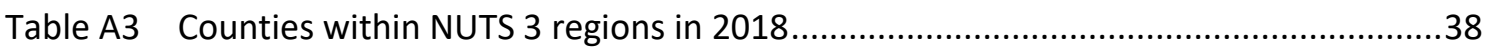

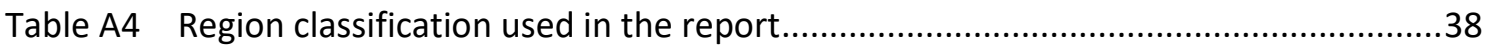




\section{EXECUTIVE SUMMARY}

- This study examines the extent to which the profile of minimum wage (MW) employees, and the impacts of the 2018 increase in the national minimum wage rate, varies by sector and region in Ireland. The research highlights variations in the importance of $\mathrm{MW}$ employment across regions and sectors. It also highlights the potential importance of considering regional and sectoral issues in any process used to determine the appropriate $\mathrm{MW}$ rate.

- The incidence of MW employment remained constant, at 8.1 per cent of employees, in 2017 and 2018. This incidence varied substantially by region in 2018, from just 5 per cent of total employees in Dublin to approximately 10 per cent of employees in the Border, Midland, and Mid-West/South East regions.

- With respect to sector, approximately 30 per cent of all employees in the accommodation and food sector are minimum wage workers. In wholesale and retail, the incidence is approximately 16 per cent, with the figure for manufacturing standing at just over 5 per cent. The average incidence of MW employment across other sectors of the economy is 4.5 per cent.

- Minimum wage employees in Dublin tend to be younger, better educated, more likely to be employed on temporary contracts and have lower tenure than most other regions. While 22 per cent of Dublin MW workers are educated to tertiary level, the figure for the national average is 17 per cent. Minimum wage workers in Dublin are also more likely to be lone parents, non-Irish nationals and are less likely to be married relative to the average national minimum wage profile.

- Minimum wage employees in the manufacturing sector are more likely to be older, male, married, working full-time, on permanent contracts and have job tenure in excess of three years. These characteristics are suggestive of 'career minimum wage workers', as opposed to transient minimum wage employees, such as young, parttime workers who are also in education. This has important implications, as career minimum wage employees may be solely reliant on statutory MW increases to boost their earnings, whereas transient MW employees are likely to naturally progress up the wage distribution as they acquire further education, training and experience.

- Our analysis indicates that the $2018 \mathrm{MW}$ increase did not lead to changes in the average hours worked of minimum wage employees generally. However, the research demonstrates that such aggregate analysis can mask heterogeneous impacts that can occur at the regional or sectoral level. In the Dublin and West regions, as well as in the manufacturing sector, the average hours worked of minimum wage employees fell in the six-month period following the minimum wage 
increase. During the same period the average hours worked of non-minimum wage employees remained constant or increased slightly in these regions and sector.

- In the six-month period following the $2018 \mathrm{MW}$ rise, average hours worked by MW employees, relative to non-MW employees, fell by 1.6 hours per week in Dublin and 1.7 hours per week in the West region. The sectoral models indicate that the average hours worked of minimum wage employees in the manufacturing sector, relative to non-MW employees, fell by 1.6 hours per week following the rate rise. The hours worked of minimum wage employees in the accommodation and food or wholesale and retail sectors were not affected.

- When the analysis was run for placebo periods, during which no change occurred in the MW rate, we found no impact on hours worked. This suggests that the observed impacts are likely related to the MW change, as opposed to diverging trends in the hours worked of minimum and non-minimum wage employees in particular sectors or regions prior to the rate change. However, we cannot fully discard this possibility due to the limitations in the number of placebo periods during which diverging trends can be tested.

- Our analysis indicates that the changes in hours worked mainly affected incumbent MW employees who were already employed in the period prior to the introduction of the 2018 rate rise. There is no evidence to support the view that the observed changes were due to compositional impacts whereby, for instance, more part-time employees entered (or left) employment in response to the rate rise, thereby altering the average hours worked of minimum wage employees in particular sectors or regions.

- The results suggest that the observed negative impacts on hours for Dublin and the West did not persist throughout 2018. While we detect an immediate reduction in hours worked of MW employees, relative to non-MW employees, in the first two quarters of 2018, the effects did not persist into the second half of the year.

- Our central results are robust to a range of specifications; however the data at hand do not allow us to identify the exact responses that brought about the observed impacts. There is a need for greater insights into exactly how firms and employees behave, following $\mathrm{MW}$ rate changes that generate a statistically significant change in hours worked, so that policy can be properly informed. This is particularly the case in instances such as those in the manufacturing sector, where impacts are observed among individuals who appear to be career minimum wage employees.

- The finding of possible heterogeneous impacts arising from the 2018 minimum wage change suggests that the existence of such variations should be monitored, particularly given that any impacts could become more persistent during periods of lower economic growth. 


\section{SECTION 1}

\section{Introduction}

A Low Pay Commission was established in Ireland in 2015 to advise the Irish government on the appropriate level of the national minimum wage. In doing so, the Low Pay Commission seeks a minimum wage that is fair and sustainable and helps as many low paid workers as possible, without creating adverse employment effects. There has been much debate, and often-conflicting evidence, about the impact of minimum wage changes on employment outcomes. Some recent international studies find adverse employment effects (e.g. Sabia et al., 2016; Galán and Puente, 2015; Meer and West, 2016), while others find little to no negative effect (e.g. Cengiz et al., 2018; Hoffman, 2016; Schmitt, 2015; Belman et al., 2015). A related strand of literature looks at the distributional impacts of minimum wage changes. While minimum wage changes have been found to reduce hourly wage inequality, the effect on household income is limited, as a large number of minimum wage workers are located in the top half of the household income distribution (Redmond et al., 2018; Logue and Callan, 2016; MaCurdy, 2015). However, for the US, Dube (forthcoming) shows that higher minimum wages are an effective means of increasing incomes of families in the bottom half of the wage distribution and thereby reducing the poverty rate.

Recent work has highlighted the importance of accounting for possible heterogeneous effects among different subgroups of workers in the population, which could be overlooked when studying overall employment outcomes. For example, Dickens et al. (2015) find no minimum wage related employment effects for full-time workers in the UK, however a negative impact is found when focusing on part-time females only. Likewise, minimum wage effects have been found to vary by age (Liu et al., 2016; Galán and Puente, 2015) and firm-type, i.e. production or non-production (Del Carpio et al., 2015).

It is also important to explore heterogeneity in the type of minimum wage employee. While minimum wages are typically set at a national level, such an aggregate approach potentially risks exposing groups of employees located in particular sectors or regions to increased risk of negative impacts. Certain groups of employees may find themselves in persistent low wage employment and are therefore solely reliant on statutory minimum wage changes to boost their incomes. We can refer to such workers as 'career minimum wage employees'. For others, such as students working part-time while in third-level education, minimum wage employment is likely to be short term in nature. Such employees will naturally transition to higher pay as they acquire skills, education and experience, and are therefore not reliant on minimum wage increases. Redmond 
et al. (2018) study the transition patterns of minimum wage workers in Ireland and find that, while the minimum wage typically acts as a stepping stone to higher pay, a substantial minority of minimum wage workers remain on the minimum wage for longer periods of time. Irish nationals, older workers, those with higher levels of education, full-time employees and those on permanent contracts are more likely to transition to higher pay compared to non-nationals, younger persons, those with lower educational attainment, part-time workers and those on temporary contracts.

The heterogeneity of minimum wage workers, and the associated effects, underpins the importance of focusing not just on the full population of minimum wage workers, but on separate subgroups. In this paper, we study both regional and sectoral variation of minimum wage employment using a unique feature of the Irish data that comes from a question that was added to Ireland's Labour Force Survey in Quarter 2 of 2016, which directly asks employees whether they are on the minimum wage. Minimum wage employment is found to be heavily concentrated in the accommodation and food and wholesale and retail sectors. These two sectors alone account for 55 per cent of minimum wage workers. The characteristics of minimum wage employees vary by sector. Minimum wage workers in the manufacturing sector are shown to have characteristics consistent with 'career minimum wage employees'. Compared to the average profile of minimum wage employees in Ireland, those employed in manufacturing tend to be older, married, predominantly male and work full-time hours. Moreover, they are heavily concentrated outside of Dublin, in the Midland and Border/Mid-East regions.

Following recommendations from the Low Pay Commission, the Irish NMW increased in January 2018 from $€ 9.25$ per hour to $€ 9.55$ per hour. When estimating the impact of the 2018 minimum wage increase on the hours worked of all minimum wage employees in Ireland, we find no effects. However, our sectoral and regional analysis uncovers significant effects, which underpin the importance of accounting for heterogeneous impacts of minimum wage policies. With regard to region, we detect statistically significant hours effects for minimum wage workers in Dublin, with a reduction, relative to non-MW employees, of 1.6 hours per week. There is also evidence to indicate a reduction of 1.7 hours per week for $\mathrm{MW}$ employees, relative to non-MW employees, in the West region. Minimum wage employees in the other four regions experience no significant changes to their hours. With regard to sector, we detect a strong negative impact for manufacturing employees, who experience a decline of 1.6 hours per week.

Our findings highlight the importance of unpacking minimum wage statistics to uncover regional and sectoral effects that may be hidden within broad, populationlevel studies. Despite the large body of research studying minimum wages, regional 
studies receive relatively little attention in the minimum wage literature. The few studies that do exist further support the importance of this type of research. Wang et al. (2019), using a US restaurant industry panel from 1990 to 2006, find substantial heterogeneity across groups and regions including positive and negative impacts. Williams (1993) finds substantial regional variation in the effect of minimum wages on employment in the US, which is largely unobserved when focusing on national-level data. Gilbert et al. (2001) find differences in the characteristics of rural and urban minimum wage workers in the UK, as well as differences in the potential impacts on earnings inequality.

The remainder of the paper proceeds as follows. In Section 2, we describe the data and outline our methodology. Section 3 presents some relevant descriptive statistics of minimum wages employees across regions and sectors. Section 4 presents our main results and Section 5 concludes. 



\section{SECTION 2}

\section{Data and methodology}

Our data come from the Irish Labour Force Survey (LFS), which is a large-scale, quarterly survey of households in Ireland. The LFS is carried out by the Central Statistics Office (CSO) and provides the official measures of unemployment in Ireland, as well as a variety of other quarterly labour force statistics for the working age population of people aged 15 and over. The LFS is a rich dataset on individual characteristics including age, sex, region of residence, nationality, education and a range of other variables related to the individual's labour market status. Of particular relevance to our study is a question, unique to the Irish Labour Force Survey, which asks individuals whether or not they are on the minimum wage. ${ }^{1}$ The question was added to the LFS in Quarter 2 of 2016. It asks individuals whether they earn (a) less than the minimum wage, (b) exactly the minimum wage or (c) more than the minimum wage. The analysis in this paper focuses on the working population of people aged 15 and over. ${ }^{2}$

As we are examining the effect of the 2018 minimum wage increase on hours worked, we focus on the years 2017 and 2018. We use usual hours worked in the analysis but our results are robust to using actual hours worked. The NUTS3 regional classification is used for a person's region of employment. This classification divides Ireland into the following eight regions: Border, West, MidWest, South East, South West, Dublin, Mid-East and the Midland. In Quarter 1, 2018, the NUTS3 boundaries were amended slightly such that county Louth changed from being included in the Border region to being included in the MidEast region and South Tipperary changed from the South East region to the MidWest region. To avoid these changes impacting our results, we group the Border and Mid-East regions together in to one region and we also group the South East and Mid-West regions together. Thus, we focus our analysis on the following six regions: West, South East/Mid-West, Dublin, Border/Mid-East, South West, and the Midland. We study three sectors which represent the highest concentration of minimum wage employment - wholesale and retail, accommodation and food, and manufacturing. More than half of all minimum wage employees are located in the first two sectors, with 8 per cent located in the manufacturing sector. The remaining minimum wage employees are located across a very broad range of sectors. As the numbers within each specific sector are too low to carry out any

Prior to the introduction of this question, ascertaining who was and was not a minimum wage employee was difficult due to the lack of precise wage data. To overcome this, researchers used a combination of income decile and hours worked to impute minimum wage status (see McGuinness and Redmond, 2019). 
meaningful analysis, we group these remaining minimum wage employees into an 'other' category.

When evaluating the effect of the 2018 minimum wage increase, it is not sufficient to compare the hours worked of minimum wage employees before and after the increase, as hours may have changed even in the absence of a policy change. To overcome this, we use a difference-in-differences (DiD) strategy that compares the change in hours worked among minimum wage employees (our treatment group) to the change in hours worked of a control group consisting of non-minimum wage employees. Therefore, the DiD strategy subtracts the change in hours, pre- and post-policy change, among the control group, from the change in hours worked among the treatment group over the same period. If the change in hours for minimum wage employees (the treatment group) is larger than the change in hours for non-minimum wage employees (the control group), then it is likely that the hours effect is attributable to the policy change. In order to avoid seasonal effects, we compare Quarters 1 and 2 in 2017 with Quarters 1 and 2 in 2018. More formally, the DiD estimator can be implemented with the following regression,

$Y_{i, t, w}=\beta_{1 w}+\beta_{2 w}$ Year $_{t}+\beta_{3 w} T_{i, w}+\beta_{4 w}$ Year $_{t} * T_{i, w}+X_{i, t, w}{ }^{\prime} \beta_{5 w}+\varepsilon_{i, t, w}$

In Equation (1), $Y_{i, t, w}$ represents hours worked for individual $i$ in year $t$ and region $w{ }^{3}$ Year $_{t}$ is a dummy variable which equals 1 for observations in Quarters 1 and 2 in 2018 , i.e. the post-policy change period, and equals 0 for observations in Quarters 1 and 2 in 2017, pre-policy change. $T_{i, w}$ is a treatment dummy variable which equals 1 if the individual is a minimum wage employee and zero if a higher paid employee. The interaction term $\mathrm{Year}_{t}{ }^{*} T_{i, w}$ represents the estimated treatment effect. We also include a vector of additional controls, $X_{i, t, w}$ which include age, education, gender, quarter, and a binary variable denoting whether the individual has children. The additional variables help to control for any compositional changes in the group of minimum wage employees over the two time periods, as well as improving the precision of the estimates.

While the LFS data do not contain precise wage information (except for minimum wage employees), workers are allocated to income deciles. However, this variable is poorly populated and information is missing for the majority of workers. Nevertheless, for the subset of employees with decile information, we observe that minimum wage employees are not represented in the higher deciles, namely deciles 9 and 10. This is to be expected, given the relatively low hourly wage rate of minimum wage employees. Therefore, to improve comparability between the 
treatment and control groups, we remove from the control group any workers in deciles 9 or 10 , for cases where decile information is available.

The existence of the minimum wage question in the LFS allows us a unique opportunity to accurately measure the incidence of the MW and effectively evaluate the impact of rate changes on outcome variables, such as hours worked, using empirical techniques that are widely used in the international literature. Nevertheless, as in all counterfactual studies of this nature, some caution is required in interpreting the results. While the use of a control group in the DiD estimator allows us to account for factors, other than the NMW change, which may have impacted the hours of all employees, researchers can never fully guarantee that other factors were not in some way impacting the results. However, for this to be the case, such factors would have to affect the treatment and control groups in different ways. When interpreting the results, it is also worth noting that we cannot easily identify the behavioural changes among either employers or employees that lead to an impact on hours. Nevertheless, we have undertaken a series of robustness tests to verify the validity of our findings. Our robustness tests also provide information on the mechanisms behind hours changes, by disentangling the hours impacts on existing MW employees from any hours changes driven by new MW employees entering (or MW workers leaving) employment after the 2018 rate rise. 



\section{SECTION 3}

\section{Descriptive analysis}

Table 1 shows the incidence of national minimum wage employment in Ireland. In both 2017 and 2018, 8.1 per cent of employees were minimum wage employees. When looking at the incidence of minimum wage employment, we define minimum wage employees as those earning on or below the national minimum wage. During the years covered in this study, 2017 and 2018, there existed subminimum wage rates for the following workers; young workers under 18 years of age, individuals who were in structured training during working hours, and inexperienced workers in their first two years of employment. ${ }^{4}$ The sub-minimum wage rates range from between 70 to 90 per cent of the full rate. However, subminimum wage employment is very rare, making up approximately one percentage point of the overall incidence (of 8 per cent). Therefore, due to small sample sizes, carrying out separate analysis on the sub-minimum wage group is not feasible. However, it does make sense to include both sub-minimum and minimum wage employees in the same group, as they are all minimum wage employees. Furthermore, an increase in the statutory minimum wage affects both types of workers, as sub-minimum and minimum wage rates both increase simultaneously.

TABLE 1 OVERALL INCIDENCE

\begin{tabular}{|l|c|c|c|}
\hline & $\mathbf{2 0 1 7}$ & $\mathbf{2 0 1 8}$ & Overall \\
\hline MW Workers & 0.081 & 0.081 & 0.081 \\
\hline Observations & 50,302 & 47,436 & 97,738 \\
\hline
\end{tabular}

Source: $\quad$ Irish Labour Force Survey 2017 and 2018.

Notes: $\quad$ LFS for all quarters in 2017 and 2018. Minimum Wage workers calculated as a percentage of all employees.

Table 2a indicates that the incidence of minimum wage employment varies substantially by region. In 2018, just 5 per cent of employees in Dublin were earning the minimum wage, compared to approximately 10 per cent in the MidWest/South East, Border/Mid-East and Midland regions. The incidence in the South West and West regions was approximately 9 per cent. The regional statistics relate to the area where the individual works, rather than where they live. However, just 8 per cent of the sample was found to work outside the region where they live. Table $2 \mathrm{~b}$ shows the regional distribution of minimum wage employees. Of the full sample of minimum wage employees nationally, there is a large concentration located in Dublin (23 per cent), the Mid-West/South East (23 per cent) and the Border/Mid-East (21 per cent) regions. The South West, West and

$4 \quad$ New criteria for sub-minimum rates, based solely on age, were implemented in March 2019. 
Midland regions account for 17 per cent, 10 per cent and 6 per cent, respectively, of all minimum wage employees in Ireland.

TABLE 2A OVERALL INCIDENCE BY REGION

\begin{tabular}{|l|c|c|c|c|c|c|}
\hline & $\begin{array}{c}\text { Border/ } \\
\text { Mid-East }\end{array}$ & West & $\begin{array}{c}\text { Mid-West/ } \\
\text { South East }\end{array}$ & South West & Dublin & Midland \\
\hline 2017 MW Workers & $\begin{array}{c}0.100 \\
(n=7,837)\end{array}$ & $\begin{array}{c}0.086 \\
(n=4,620)\end{array}$ & $\begin{array}{c}0.107 \\
(n=8,866)\end{array}$ & $\begin{array}{c}0.095 \\
(n=7,250)\end{array}$ & $\begin{array}{c}0.053 \\
(n=18,155)\end{array}$ & $\begin{array}{c}0.099 \\
(n=2,231)\end{array}$ \\
\hline 2018 MW Workers & $\begin{array}{c}0.105 \\
(n=8,163)\end{array}$ & $\begin{array}{c}0.091 \\
(n=4,124)\end{array}$ & $\begin{array}{c}0.107 \\
(n=9,977)\end{array}$ & $\begin{array}{c}0.085 \\
(n=7,330)\end{array}$ & $\begin{array}{c}0.050 \\
(n=16,999)\end{array}$ & $\begin{array}{c}0.102 \\
(n=2,464)\end{array}$ \\
\hline $\begin{array}{l}\text { Overall MW Workers } \\
\text { (2017 and 2018) }\end{array}$ & 0.103 & 0.088 & 0.107 & 0.090 & 0.052 & 0.100 \\
\hline Observations & 16,000 & 8,744 & 16,843 & 14,580 & 35,154 & 4,695 \\
\hline
\end{tabular}

Source: $\quad$ Irish Labour Force Survey 2017 and 2018.

Notes: $\quad$ LFS for all quarters in 2017 and 2018. Minimum Wage workers calculated as a percentage of all employees. Region of work is used in the analysis.

TABLE 2B REGIONAL VARIATION

\begin{tabular}{l|c|c|c|c|c|c}
\hline & $\begin{array}{c}\text { Border/ } \\
\text { Mid-East }\end{array}$ & West & $\begin{array}{c}\text { Mid-West/ } \\
\text { South East }\end{array}$ & South West & Dublin & Midland \\
\hline 2017 MW Workers & $\begin{array}{c}0.195 \\
(n=782)\end{array}$ & $\begin{array}{c}0.099 \\
(n=396)\end{array}$ & $\begin{array}{c}0.236 \\
(n=946)\end{array}$ & $\begin{array}{c}0.173 \\
(n=692)\end{array}$ & $\begin{array}{c}0.242 \\
(n=971)\end{array}$ & $\begin{array}{c}0.055 \\
(n=220)\end{array}$ \\
\hline 2018 MW Workers & $\begin{array}{c}0.226 \\
(n=860)\end{array}$ & $\begin{array}{c}0.099 \\
(n=376)\end{array}$ & $\begin{array}{c}0.224 \\
(n=855)\end{array}$ & $\begin{array}{c}0.164 \\
(n=624)\end{array}$ & $\begin{array}{c}0.222 \\
(n=847)\end{array}$ & $\begin{array}{c}0.066 \\
(n=251)\end{array}$ \\
\hline $\begin{array}{l}\text { Overall MW Workers } \\
\text { (2017 and 2018) }\end{array}$ & 0.21 & 0.099 & 0.230 & 0.168 & 0.232 & 0.060 \\
\hline Observations & 1,642 & 772 & 1,801 & 1,316 & 1,818 & 471 \\
\hline
\end{tabular}

Source: $\quad$ Irish Labour Force Survey 2017 and 2018.

Notes: $\quad$ LFS for all quarters in 2017 and 2018. Minimum Wage workers calculated as a percentage of all employees. Region of work is used in the analysis.

We also observe substantial variation in the incidence of minimum wage employment across sectors. Table 3a shows that, in 2018, 16 per cent of all employees in the wholesale and retail sector and 30 per cent of all employees in the accommodation and food sector were minimum wage employees. Table $3 \mathrm{~b}$ indicates that these two sectors alone account for 54 per cent of all minimum wage employees in Ireland. Approximately 5 per cent of all manufacturing workers are minimum wage employees, accounting for 8 per cent of all minimum wage employment in Ireland. The remaining 37 per cent of minimum wage workers in Ireland are widely distributed across other sectors of the labour market. ${ }^{5}$

The other sectors in which minimum wage employees made up more than 1 per cent of all employees included the following: Crop and animal production, hunting and related service activities; Construction of buildings; Specialised construction activities; Land transport and transport via pipelines; Services to buildings and landscape activities; Public administration and defence (compulsory social security); Education; Human health activities; Residential care activities; Social work activities without accommodation; Sports activities and amusement and recreation activities; and Other personal service activities. 


\begin{tabular}{|l|c|c|c|c|}
\hline & $\begin{array}{c}\text { Wholesale and } \\
\text { Retail }\end{array}$ & $\begin{array}{c}\text { Accommodation } \\
\text { and Food }\end{array}$ & Manufacturing & Other \\
\hline 2017 MW Workers & $\begin{array}{c}0.160 \\
(n=7,146)\end{array}$ & $\begin{array}{c}0.292 \\
(n=3,694)\end{array}$ & $\begin{array}{c}0.053 \\
(n=6,146)\end{array}$ & $\begin{array}{c}0.045 \\
(n=33,225)\end{array}$ \\
\hline 2018 MW Workers & $\begin{array}{c}0.160 \\
(n=6,577)\end{array}$ & $\begin{array}{c}0.304 \\
(n=3,405)\end{array}$ & $\begin{array}{c}0.054 \\
(n=5,675)\end{array}$ & $\begin{array}{c}0.046 \\
(n=31,657)\end{array}$ \\
\hline $\begin{array}{l}\text { Overall MW Workers } \\
\text { (2017 and 2018) }\end{array}$ & 0.16 & 0.298 & 0.053 & 0.045 \\
\hline Observations & 13,723 & 7,099 & 11,821 & 64,882 \\
\hline
\end{tabular}

Source: $\quad$ Irish Labour Force Survey 2017 and 2018.

Notes: $\quad$ LFS for all quarters in 2017 and 2018. Minimum Wage workers calculated as a percentage of all employees.

TABLE 3B SECTORAL VARIATION OF MINIMUM WAGE WORKERS

\begin{tabular}{l|c|c|c|c|}
\hline & $\begin{array}{c}\text { Wholesale and } \\
\text { Retail }\end{array}$ & $\begin{array}{c}\text { Accommodation } \\
\text { and Food }\end{array}$ & Manufacturing & Other \\
\hline 2017 MW Workers & $\begin{array}{c}0.282 \\
(n=1,141)\end{array}$ & $\begin{array}{c}0.266 \\
(n=1,078)\end{array}$ & $\begin{array}{c}0.080 \\
(n=324)\end{array}$ & $\begin{array}{c}0.371 \\
(n=1,503)\end{array}$ \\
\hline 2018 MW Workers & $\begin{array}{c}0.274 \\
(n=1,052)\end{array}$ & $\begin{array}{c}0.269 \\
(n=1,035)\end{array}$ & $\begin{array}{c}0.080 \\
(n=308)\end{array}$ & $\begin{array}{c}0.376 \\
(n=1,446)\end{array}$ \\
\hline $\begin{array}{l}\text { Overall MW Workers } \\
\text { (2017 and 2018) }\end{array}$ & 27.8 & 26.8 & 0.080 & 37.4 \\
\hline Observations & 2,193 & 2,113 & 632 & 2,949 \\
\hline
\end{tabular}

Source: $\quad$ Irish Labour Force Survey 2017 and 2018.

Notes: $\quad$ LFS for all quarters in 2017 and 2018. Minimum Wage workers calculated as a percentage of all employees.

Table 4 examines the mean characteristics of MW employees by region across a range of dimensions including gender, age, education, marital status, household composition, hours worked, contractual status, firm size and sector. The final column of the table provides the basis for comparison by listing the average characteristics of the full national sample of minimum wage employees. We undertake t-tests that indicate whether the regional averages vary in a statistically significant way from the national average. It is apparent that minimum wage employees' characteristics in Dublin are quite different to the characteristics of minimum wage employees at the national average level. Firstly, those on the minimum wage in Dublin are younger and better educated than in the rest of the country. The average age of minimum wage employees in Dublin is 29 , compared to approximately 31 elsewhere. While 22 per cent of the Dublin workers are educated to tertiary level, the figure for the national average is 17. Minimum wage workers in Dublin are also more likely to be lone parents, non-Irish nationals, have temporary contracts, have lower tenure, and are less likely to be married relative to the average national minimum wage profile. It is also notable that minimum wage workers in the manufacturing sector are predominantly located outside of Dublin; just 3 per cent of minimum wage employees in Dublin are in the manufacturing sector, whereas the corresponding figure for other regions is 
between 9 and 10 per cent. Other regional based differences include: (i) higher proportions of married MW employees in the West and Midland regions, (ii) lower proportions of MW employees working part-time in the West region, and (iii) a lower percentage of MW employees employed in small businesses in Dublin and the South West.

TABLE 4

AVERAGE CHARACTERISTICS OF MINIMUM WAGE WORKERS BY REGION IN 2017 AND 2018

\begin{tabular}{|c|c|c|c|c|c|c|c|}
\hline & $\begin{array}{c}\text { Border/Mid- } \\
\text { East }\end{array}$ & West & $\begin{array}{c}\text { Mid- } \\
\text { West/South } \\
\text { East }\end{array}$ & $\begin{array}{l}\text { South } \\
\text { West }\end{array}$ & Dublin & Midland & Ireland \\
\hline Age & 31.54 & $32.70 * * *$ & 31.60 & 30.80 & $28.76 * * *$ & $33.10 * * *$ & 31.01 \\
\hline Female & 0.55 & 0.56 & $0.58 * *$ & 0.56 & $0.51 * * *$ & 0.56 & 0.55 \\
\hline Lone parent & 0.22 & $0.17 * *$ & $0.19 *$ & $0.18^{*}$ & $0.26 * * *$ & 0.20 & 0.21 \\
\hline Single household & $0.12 * * *$ & $0.24 * * *$ & 0.16 & 0.14 & 0.17 & 0.14 & 0.16 \\
\hline Married & 0.25 & $0.31 * * *$ & 0.23 & 0.24 & $0.20 * * *$ & $0.30 * * *$ & 0.24 \\
\hline Irish & 0.84 & $0.79 * * *$ & $0.87^{* * *}$ & 0.84 & $0.78 * * *$ & 0.81 & 0.83 \\
\hline Nationality other & $0.02 * * *$ & 0.04 & $0.02 * * *$ & $0.03^{* * *}$ & $0.10 * * *$ & 0.05 & 0.04 \\
\hline EU & 0.14 & 0.17 & 0.11 & 0.13 & 0.12 & 0.14 & 0.13 \\
\hline No children & 0.63 & 0.65 & 0.63 & 0.63 & 0.63 & 0.62 & 0.63 \\
\hline 1 to 2 children & 0.32 & 0.30 & 0.33 & 0.32 & 0.33 & 0.31 & 0.32 \\
\hline $\begin{array}{l}\text { More than } 2 \\
\text { children }\end{array}$ & 0.05 & 0.05 & 0.05 & 0.04 & 0.04 & $0.07 *$ & 0.05 \\
\hline Low ISCED & $0.25^{* *}$ & 0.24 & 0.23 & 0.23 & $0.18^{* * *}$ & 0.22 & 0.22 \\
\hline Medium ISCED & 0.62 & 0.60 & 0.62 & 0.59 & 0.60 & 0.63 & 0.61 \\
\hline High ISCED & $0.13^{* * *}$ & 0.17 & $0.14^{* * *}$ & 0.18 & $0.22 * * *$ & 0.15 & 0.17 \\
\hline $\begin{array}{l}\text { Temporary } \\
\text { Contract }\end{array}$ & 0.32 & $0.27 * * *$ & 0.32 & 0.34 & $0.36 * *$ & 0.32 & 0.33 \\
\hline Hours Worked & $23.59 *$ & 25.02 & 23.78 & 24.93 & 24.74 & 23.89 & 24.34 \\
\hline Part time & $0.62 * * *$ & $0.54^{* * *}$ & 0.59 & 0.58 & 0.58 & 0.61 & 0.59 \\
\hline $\begin{array}{l}\text { Firms with } \leq 10 \\
\text { workers }\end{array}$ & 0.35 & 0.37 & $0.42 * * *$ & $0.33^{* *}$ & $0.30 * * *$ & $0.44 * * *$ & 0.36 \\
\hline $\begin{array}{l}\text { Approx } 1 \text { year } \\
\text { tenure }\end{array}$ & 0.52 & $0.47^{* * *}$ & $0.51^{* *}$ & 0.55 & $0.63^{* * *}$ & $0.49 * *$ & 0.54 \\
\hline $\begin{array}{l}\text { Approx } 2 \text { years } \\
\text { tenure }\end{array}$ & $0.16^{* *}$ & 0.14 & 0.13 & 0.14 & 0.13 & 0.14 & 0.14 \\
\hline $\begin{array}{l}\text { Approx } 3 \text { years } \\
\text { tenure }\end{array}$ & 0.08 & $0.10 * *$ & $0.09 *$ & 0.07 & 0.07 & 0.08 & 0.08 \\
\hline $\begin{array}{l}\text { More than } 3 \\
\text { years tenure }\end{array}$ & 0.24 & $0.29 * * *$ & $0.27^{* *}$ & 0.24 & $0.17^{* * *}$ & $0.30 * * *$ & 0.24 \\
\hline $\begin{array}{l}\text { Wholesale and } \\
\text { Retail }\end{array}$ & 0.28 & 0.27 & 0.26 & $0.30 *$ & 0.28 & 0.25 & 0.28 \\
\hline $\begin{array}{l}\text { Accommodation } \\
\text { and Food }\end{array}$ & 0.26 & 0.28 & 0.27 & 0.26 & 0.27 & 0.28 & 0.27 \\
\hline Manufacturing & $0.10^{* * *}$ & 0.09 & $0.09 *$ & 0.09 & $0.03 * * *$ & $0.10^{*}$ & 0.08 \\
\hline Other & 0.36 & 0.36 & 0.38 & $0.35^{*}$ & $0.41 * * *$ & 0.36 & 0.37 \\
\hline Observations & 1,642 & 772 & 1,801 & 1,316 & 1,818 & 471 & 7,901 \\
\hline
\end{tabular}



level, ** at 0.05 and $*$ at 0.10 .

Table 5 examines the mean characteristics of minimum wage employees by sector of employment. Minimum wage employees employed in the manufacturing sector look very different from minimum wage workers employed in other sectors of the economy across a range of characteristics. In particular, compared to the national average, minimum wage employees in manufacturing are more likely to be older, male, non-Irish nationals, married, working full-time hours, in permanent positions and in firms with more than ten workers. For example, 79 per cent of workers in the manufacturing sector are on permanent contracts and 79 per cent are in fulltime positions, which compares to national averages for MW employees of 67 and 41 per cent respectively. The characteristics of minimum wage employees in the manufacturing sector are therefore consistent with 'career minimum wage employees'. This has potentially important policy implications. Career minimum wage employees will be reliant on statutory increases in the national minimum wage to increase their incomes. It is also likely that their income from work represents a large component of their household income, meaning that any increase in the minimum wage could improve the standard of living of these households. On the other hand, the minimum wage is likely to be a short-term situation for young, part-time workers who are highly educated. These transient minimum wage workers will not be as reliant on statutory increases in the minimum wage to boost their incomes as they may naturally progress up the wage scale as they acquire further education, training and experience.

Other sectoral variations of note include (i) a higher than average share of Irish MW employees in wholesale and retail, (ii) above average shares of part-time MW employees in both accommodation and food and wholesale and retail, (iii) lower employment tenure in accommodation and food and (iv) a higher incidence of female MW workers in the accommodation and food and wholesale and retail sector. 


\begin{tabular}{|c|c|c|c|c|c|}
\hline & $\begin{array}{c}\text { Wholesale and } \\
\text { Retail }\end{array}$ & $\begin{array}{c}\text { Accommodation } \\
\text { and Food }\end{array}$ & Manufacturing & Other & All Sectors \\
\hline & Mean & Mean & Mean & Mean & Mean \\
\hline Age & $28.28 * * *$ & $27.42 * * *$ & $34.05 * * *$ & $34.92 * * *$ & 31.01 \\
\hline Female & $0.58 * * *$ & $0.62 * * *$ & $0.34 * * *$ & $0.52 * * *$ & 0.55 \\
\hline Lone parent & 0.20 & $0.24 * * *$ & $0.15^{* * *}$ & 0.21 & 0.21 \\
\hline Single household & $0.12^{* * *}$ & $0.17 * *$ & $0.18^{*}$ & 0.16 & 0.16 \\
\hline Married & $0.19 * * *$ & $0.19 * * *$ & $0.33 * * *$ & $0.29 * * *$ & 0.24 \\
\hline Irish & $0.89 * * *$ & $0.76 * * *$ & $0.69 * * *$ & $0.85 * * *$ & 0.83 \\
\hline Nationality other & $0.02 * * *$ & $0.07 * * *$ & $0.06 *$ & $0.04 *$ & 0.04 \\
\hline EU & $0.09 * * *$ & $0.16 * * *$ & $0.25 * * *$ & $0.11^{* *}$ & 0.13 \\
\hline No children & 0.62 & 0.64 & 0.63 & 0.64 & 0.63 \\
\hline 1 to 2 children & 0.33 & 0.32 & 0.33 & 0.31 & 0.32 \\
\hline $\begin{array}{l}\text { More than } 2 \\
\text { children }\end{array}$ & 0.05 & 0.04 & 0.04 & 0.05 & 0.05 \\
\hline LOW ISCED & 0.21 & 0.21 & $0.17 * * *$ & $0.25^{* * *}$ & 0.22 \\
\hline Medium ISCED & $0.65 * * *$ & 0.63 & $0.68 * * *$ & $0.56^{* * *}$ & 0.61 \\
\hline High ISCED & $0.14^{* * *}$ & 0.17 & 0.15 & $0.19 * * *$ & 0.17 \\
\hline $\begin{array}{l}\text { Temporary } \\
\text { Contract }\end{array}$ & 0.33 & $0.36 * *$ & $0.21 * * *$ & 0.33 & 0.33 \\
\hline Hours Worked & $21.64 * * *$ & $20.34 * * *$ & $34.48 * * *$ & $27.03 * * *$ & 24.34 \\
\hline Part-time & $0.68 * * *$ & $0.71 * * *$ & $0.21 * * *$ & $0.51 * * *$ & 0.59 \\
\hline $\begin{array}{l}\text { Firms with } \leq 10 \\
\text { workers }\end{array}$ & 0.37 & $0.28 * * *$ & $0.16^{* * *}$ & $0.46 * * *$ & 0.36 \\
\hline $\begin{array}{l}\text { Approx } 1 \text { year } \\
\text { tenure }\end{array}$ & 0.55 & $0.61 * * *$ & 0.52 & $0.49 * * *$ & 0.54 \\
\hline $\begin{array}{l}\text { Approx } 2 \text { years } \\
\text { tenure }\end{array}$ & 0.15 & 0.14 & $0.11^{* *}$ & 0.14 & 0.14 \\
\hline $\begin{array}{l}\text { Approx } 3 \text { years } \\
\text { tenure }\end{array}$ & 0.07 & 0.08 & 0.09 & 0.08 & 0.08 \\
\hline $\begin{array}{l}\text { More than } 3 \text { years } \\
\text { tenure }\end{array}$ & 0.23 & $0.17^{* * *}$ & $0.29 * * *$ & $0.29 * * *$ & 0.24 \\
\hline Border/Mid-East & 0.21 & 0.20 & $0.27 * * *$ & 0.20 & 0.21 \\
\hline West & 0.10 & 0.10 & 0.11 & 0.09 & 0.10 \\
\hline $\begin{array}{l}\text { Mid-West/South } \\
\text { East }\end{array}$ & 0.22 & 0.23 & $0.26 *$ & 0.23 & 0.23 \\
\hline South West & 0.18 & 0.17 & 0.18 & 0.16 & 0.17 \\
\hline Dublin & 0.24 & 0.24 & $0.10 * * *$ & $0.25^{* *}$ & 0.23 \\
\hline Midland & 0.06 & 0.06 & $0.08^{*}$ & 0.06 & 0.06 \\
\hline Observations & 2,193 & 2,113 & 632 & 2,949 & 7,901 \\
\hline
\end{tabular}

Source: $\quad$ Irish Labour Force Survey 2017 and 2018.

Note: $\quad$ T-test of differences in sample means between each sector and overall sectors performed with *** denoting significance at 0.01 level, $* *$ at 0.05 and $*$ at 0.10 .

Finally, Table 6 compares the characteristics of minimum wage employees (the treatment group) and those earning above the minimum wage (the control group). Not surprisingly, and consistent with other research by Redmond et al. (2018), some differences emerge in the average characteristics of the two groups. Relative 
to the control group, minimum wage employees are much more likely to be younger, less well educated, lone parents, on temporary contracts, non-Irish, in part-time employment, located in smaller firms and have shorter employment tenures. As shown in Table 6, while there are some significant differences in the characteristics of the treatment and control groups, these differences are stable over time. This is important for our difference-in-differences methodology, which subtracts the change in hours from 2017 to 2018 in the control group, from the change in hours over the same period in the treated group. If there were substantial changes over time in the average characteristics of one group only, such that the differences in the characteristics of both groups were not stable over time, this would raise the likelihood that any observed hours effect was attributable to changes in characteristics as opposed to the MW change. However, Table 6 demonstrates that this does not appear to be an issue in our analysis. 
TABLE 6 CHARACTERISTICS OF TREATED AND CONTROL BY YEAR

\begin{tabular}{|c|c|c|c|c|}
\hline & Control 2017 & Treated 2017 & Control 2018 & Treated 2018 \\
\hline & Mean & Mean & Mean & Mean \\
\hline Age & $41.29 * * *$ & 31.46 & $42.07 * * *$ & 31.39 \\
\hline Female & $0.52 * * *$ & 0.58 & $0.52 * *$ & 0.55 \\
\hline Lone parent & $0.11 * *$ & 0.21 & $0.11^{* * *}$ & 0.21 \\
\hline Single household & $0.15^{* * *}$ & 0.18 & $0.14^{* *}$ & 0.16 \\
\hline Married & $0.56 * * *$ & 0.26 & $0.59 * * *$ & 0.24 \\
\hline Irish & $0.88 * * *$ & 0.77 & $0.89 * * *$ & 0.85 \\
\hline Nationality other & $0.03 * * *$ & 0.05 & $0.02 * * *$ & 0.03 \\
\hline EU & $0.10 * *$ & 0.17 & $0.09 * * *$ & 0.12 \\
\hline No children & $0.57 * *$ & 0.59 & $0.57^{* * *}$ & 0.67 \\
\hline 1 to 2 children & 0.35 & 0.35 & $0.34 * * *$ & 0.29 \\
\hline $\begin{array}{l}\text { More than } 2 \\
\text { children }\end{array}$ & $0.08 * * *$ & 0.06 & $0.09 * * *$ & 0.04 \\
\hline Low ISCED & $0.11^{* * *}$ & 0.21 & $0.11^{* * *}$ & 0.21 \\
\hline Medium ISCED & $0.37 * * *$ & 0.60 & $0.37^{* * *}$ & 0.62 \\
\hline High ISCED & $0.52 * * *$ & 0.19 & $0.51 * * *$ & 0.17 \\
\hline Temporary Contract & $0.06 * * *$ & 0.27 & $0.07^{* * *}$ & 0.32 \\
\hline Hours Worked & $34.03 * * *$ & 23.45 & $34.73 * * *$ & 24.41 \\
\hline Part-time & $0.19 * * *$ & 0.59 & $0.19 * * *$ & 0.59 \\
\hline $\begin{array}{l}\text { Firms with } \leq 10 \\
\text { workers }\end{array}$ & $0.23 * * *$ & 0.38 & $0.20 * * *$ & 0.35 \\
\hline $\begin{array}{l}\text { Approx } 1 \text { year } \\
\text { tenure }\end{array}$ & $0.18^{* * *}$ & 0.49 & $0.19 * * *$ & 0.48 \\
\hline $\begin{array}{l}\text { Approx } 2 \text { years } \\
\text { tenure }\end{array}$ & $0.09 * * *$ & 0.17 & $0.09 * * *$ & 0.15 \\
\hline $\begin{array}{l}\text { Approx } 3 \text { years } \\
\text { tenure }\end{array}$ & 0.07 & 0.08 & $0.08 * * *$ & 0.10 \\
\hline $\begin{array}{l}\text { More than } 3 \text { years } \\
\text { tenure }\end{array}$ & $0.66 * * *$ & 0.25 & $0.64 * * *$ & 0.26 \\
\hline $\begin{array}{l}\text { Wholesale and } \\
\text { Retail }\end{array}$ & $0.13^{* * *}$ & 0.28 & $0.13^{* * *}$ & 0.27 \\
\hline Accom. and Food & $0.06 * * *$ & 0.27 & $0.06 * * *$ & 0.27 \\
\hline Manufacturing & $0.12^{* * *}$ & 0.08 & $0.12^{* * *}$ & 0.08 \\
\hline Other & $0.68 * * *$ & 0.37 & $0.69 * * *$ & 0.38 \\
\hline Observations & 24,623 & 2,101 & 19,418 & 2,031 \\
\hline
\end{tabular}

Source: $\quad$ Irish Labour Force Survey 2017 and 2018.

Notes: $\quad$ This analysis includes Quarters 1 and 2 only. Top two income deciles for control group are also excluded. T-test of differences in sample means between treated and control performed with *** denoting significance at 0.01 level, $* *$ at 0.05 and $*$ at 0.10 . 


\section{SECTION 4}

\section{Results}

We next present the results from our empirical methodology. It is important to stress that it is almost impossible to be certain that we are identifying a causal impact of a change in the $2018 \mathrm{MW}$ rate on hours worked. Nevertheless, we adopt an empirical strategy that attempts to remove particular forms of bias that can potentially impact our estimates, thus allowing us to point towards potentially causal effects with a greater degree of certainty.

In Table 7 we estimate Equation (1) for all employees, and then separately for temporary employees. ${ }^{6}$ This is done on the grounds that McGuinness and Redmond (2018) found a statistically significant impact following the introduction of the $2016 \mathrm{MW}$ rate rise that was more pronounced among temporary employees. ${ }^{7}$ We estimate each model both with and without control variables to test the sensitivity of the estimate to possible compositional changes among the characteristics of the treatment and control groups. The DiD coefficients are not statistically significant in all four models. This indicates that the 2018 increase in the national minimum wage did not lead to a change in the overall average hours worked of minimum wage employees in Ireland. ${ }^{8}$

$6 \quad$ The sample sizes will be smaller than for the descriptive analysis, as the models are run using two quarters of data from each year.

$7 \quad$ We can estimate the full model on the subset of temporary workers. However, due to restricted sample sizes, we cannot separately estimate temporary contract models for each region and sector.

8 The coefficients associated with the additional control variables behave as expected, indicating that the average number of hours worked is lower for females and those with children. Those with higher levels of education work more hours. 
TABLE 7

DIFFERENCE-IN-DIFFERENCES ESTIMATES OF THE EFFECT OF MINIMUM WAGE CHANGE ON HOURS WORKED

\begin{tabular}{|c|c|c|c|c|}
\hline & (1) & (2) & (3) & (4) \\
\hline VARIABLES & Overall & Overall & $\begin{array}{c}\text { Temporary } \\
\text { workers }\end{array}$ & $\begin{array}{c}\text { Temporary } \\
\text { workers }\end{array}$ \\
\hline \multirow[t]{2}{*}{ DiD } & 0.165 & -0.0652 & 0.996 & 1.189 \\
\hline & $(0.341)$ & $(0.323)$ & $(0.893)$ & $(0.858)$ \\
\hline \multirow[t]{2}{*}{ Time } & 0.113 & $0.190 * *$ & -0.101 & -0.171 \\
\hline & $(0.0983)$ & $(0.0927)$ & $(0.488)$ & $(0.468)$ \\
\hline \multirow[t]{2}{*}{ Minimum Wage } & $-9.726 * * *$ & $-8.852 * * *$ & $-8.593 * * *$ & $-6.699 * * *$ \\
\hline & $(0.239)$ & $(0.234)$ & $(0.646)$ & $(0.650)$ \\
\hline \multirow[t]{2}{*}{ Age } & & $-0.0325 * * *$ & & -0.00649 \\
\hline & & $(0.00381)$ & & $(0.0144)$ \\
\hline \multirow[t]{2}{*}{ Female } & & $-6.911 * * *$ & & $-5.244 * * *$ \\
\hline & & $(0.0892)$ & & $(0.400)$ \\
\hline \multirow[t]{2}{*}{ Children (binary) } & & $-0.560 * * *$ & & -0.0259 \\
\hline & & (0.0899) & & $(0.421)$ \\
\hline \multirow[t]{2}{*}{$\begin{array}{l}\text { Medium ISCED (ref } \\
=\text { low ISCED) }\end{array}$} & & $2.005^{* * *}$ & & $4.611 * * *$ \\
\hline & & $(0.150)$ & & $(0.593)$ \\
\hline \multirow[t]{2}{*}{ High ISCED } & & $4.454 * * *$ & & $9.129 * * *$ \\
\hline & & $(0.150)$ & & $(0.622)$ \\
\hline \multirow[t]{2}{*}{$2^{\text {nd }}$ Quarter } & & 0.0751 & & $0.989 * *$ \\
\hline & & $(0.0883)$ & & $(0.392)$ \\
\hline \multirow[t]{2}{*}{ Constant } & $35.29 * * *$ & $37.37^{* * *}$ & $28.34^{* * *}$ & $24.59 * * *$ \\
\hline & $(0.0655)$ & $(0.241)$ & $(0.346)$ & $(0.902)$ \\
\hline Observations & 46,460 & 45,520 & 3,614 & 3,585 \\
\hline R-squared & 0.064 & 0.189 & 0.083 & 0.168 \\
\hline
\end{tabular}

Source: $\quad$ Irish Labour Force Survey 2017 and 2018.

Notes: $\quad$ The DiD model compares Q1/Q2 2017 with Q1/Q2 2018. Standard errors in parentheses with significance levels *** p<0.01, $* * p<0.05, * p<0.1$.

Tables 8 and 9 present the results for Equation (1), estimated separately by region and sector. While no overall impact was observed for all MW employees, there is evidence of heterogeneous impacts across sectors and regions. The sectoral models in Table 8 indicate that only minimum wage employees in the manufacturing sector recorded a fall in the average hours worked. Relative to nonminimum wage employees in the same sector, minimum wage employees in manufacturing experienced a reduction of 1.6 hours per week. No significant effects were detected for minimum wage employees in the accommodation and food and wholesale and retail sectors. The hours of minimum wage employees in the 'other' sectors increased by 0.9 hours per week, relative to non-minimum wage employees in the same sectors, following the 2018 rate rise. However, the impact is only marginally statistically significant. The finding with regard to manufacturing is potentially concerning given the evidence presented earlier which indicates that 
such employees are likely to be career minimum wage employees who are working in full-time, permanent positions. A drop in hours for these types of employees may be more damaging than a drop in hours for a young, highly educated, parttime employee, for which minimum wage employment may simply be a temporary stepping stone to higher pay.

TABLE 8

DIFFERENCE-IN-DIFFERENCES ESTIMATES OF THE EFFECT OF MINIMUM WAGE CHANGE ON HOURS WORKED BY SECTOR

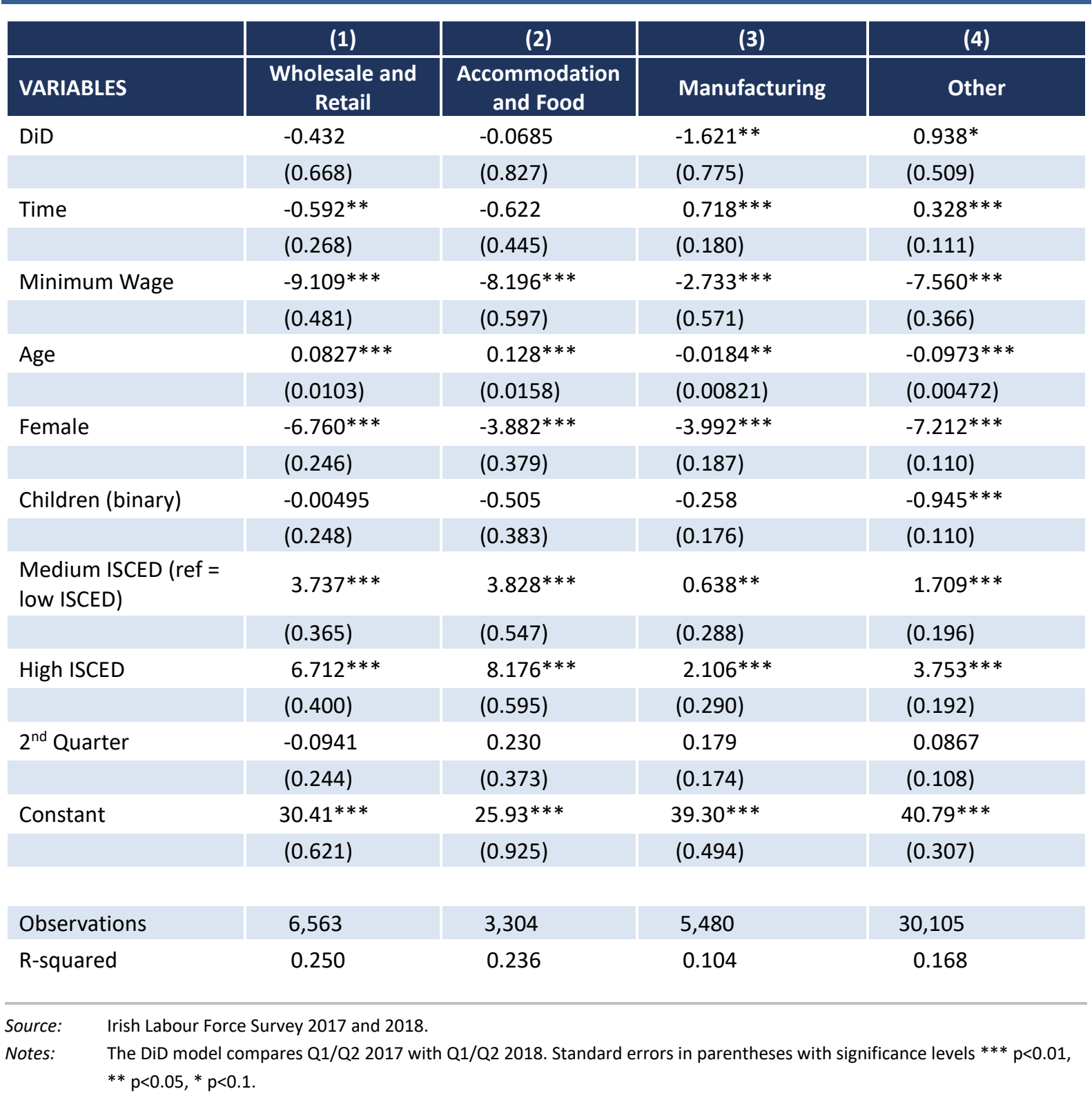

With respect to region, following the $2018 \mathrm{MW}$ increase, the average weekly hours worked by minimum wage employees, relative to non-minimum wage employees in the same region, fell by 1.6 hours in Dublin and 1.7 hours in the West region. However, the results for the West region are only marginally statistically significant. There were no statistically significant effects detected in any of the 
other four regions. These results are robust to the inclusion of additional controls for sector in the regional models, and for region in the sectoral models.

The DiD estimates compare changes in the treatment group to changes in the control group. As such, hours changes in either the treatment or control group, or some combination of both, can drive the results. For example, the negative hours effect observed for MW employees could be due to hours worked of MW employees declining, while hours worked of non-MW employees remained the same. On the other hand, we could get a negative hours effect if the hours worked of MW employees stayed constant, but the hours of non-MW workers increased. To disentangle what is driving our results, we look at how the average hours of both groups actually changed over the two periods. For the West region, the effect is fully driven by a reduction in hours of MW employees: over the two time periods, the hours worked of MW employees fell by approximately 1.7 hours per week (or 6 per cent), while the hours of non-MW employees remained stable. For Dublin, the effect was also primarily driven by a fall in hours of MW employees. Over the two time periods, the hours worked of MW employees in Dublin fell by 3 per cent, with a simultaneous increase of just under 1 per cent for hours of non-MW workers. For manufacturing, there was a 3.5 per cent decline in the hours worked of MW employees, while non-MW employees in the manufacturing sector saw an increase in hours of approximately 1.5 per cent. What these results show is that the negative hours effects detected in our DiD analysis were either fully, or predominantly, driven by actual declines in the average hours worked of MW employees.

Our analysis is based on the individual's region of work. However, in order to assess the extent to which the choice of regional variable (i.e. region of work or region of residence) influences our results, we re-estimate our models using region of residence. The results are shown in Table 10. Using region of residence, we again see a fall in the hours worked of minimum wage employees in Dublin and the West. The results in this specification for Dublin and the West are of a slightly higher magnitude and of increased statistical significance in comparison to the region of work specification. There is also a weakly statistically significant fall in hours in the Midland region, as well as marginally significant increases in hours in the MidWest/South East and South West regions. Nevertheless, this robustness test tends to confirm the decline in hours worked in both Dublin and the West regions among minimum wage workers following the introduction of the 2018 rate. 


\begin{tabular}{|c|c|c|c|c|c|c|}
\hline & (1) & (2) & (3) & (4) & (5) & (6) \\
\hline VARIABLES & $\begin{array}{l}\text { Border/ } \\
\text { Mid-East }\end{array}$ & West & $\begin{array}{l}\text { Mid-West/ } \\
\text { South East }\end{array}$ & South West & Dublin & Midland \\
\hline \multirow[t]{2}{*}{ DiD } & -0.195 & $-1.693 *$ & 0.730 & 1.260 & $-1.621^{* *}$ & -1.332 \\
\hline & $(0.748)$ & (1.010) & (0.698) & (0.791) & $(0.636)$ & (1.406) \\
\hline \multirow[t]{2}{*}{ Time } & $0.438^{*}$ & 0.216 & 0.158 & 0.361 & $0.303^{* *}$ & 0.693 \\
\hline & $(0.237)$ & $(0.293)$ & $(0.231)$ & $(0.242)$ & (0.149) & (0.429) \\
\hline \multirow[t]{2}{*}{ Minimum Wage } & $-9.013 * * *$ & $-7.041 * * *$ & $-8.720 * * *$ & $-8.699 * * *$ & $-8.903 * * *$ & $-8.914 * * *$ \\
\hline & $(0.569)$ & $(0.758)$ & $(0.511)$ & $(0.570)$ & $(0.432)$ & (1.023) \\
\hline \multirow[t]{2}{*}{ Age } & $-0.0294 * * *$ & $-0.0788^{* * *}$ & $-0.0263^{* * *}$ & $-0.0403 * * *$ & $-0.0205 * * *$ & -0.0189 \\
\hline & $(0.00964)$ & $(0.0122)$ & $(0.00941)$ & $(0.00997)$ & $(0.00624)$ & $(0.0180)$ \\
\hline \multirow[t]{2}{*}{ Female } & $-7.220 * * *$ & $-5.623 * * *$ & $-7.667 * * *$ & $-8.037 * * *$ & $-5.873 * * *$ & $-6.372 * * *$ \\
\hline & $(0.230)$ & $(0.285)$ & $(0.221)$ & $(0.233)$ & $(0.144)$ & $(0.418)$ \\
\hline \multirow[t]{2}{*}{$\begin{array}{l}\text { Children } \\
\text { (binary) }\end{array}$} & $-0.539 * *$ & $-0.583^{* *}$ & -0.228 & $-0.869 * * *$ & $-0.647^{* * *}$ & 0.517 \\
\hline & $(0.232)$ & $(0.284)$ & $(0.222)$ & $(0.236)$ & $(0.146)$ & (0.419) \\
\hline \multirow[t]{2}{*}{$\begin{array}{l}\text { Medium ISCED } \\
\text { (ref = low } \\
\text { ISCED) }\end{array}$} & $2.619 * * *$ & $1.308^{* * *}$ & $2.299 * * *$ & $2.204^{* * *}$ & $1.963 * * *$ & 0.929 \\
\hline & $(0.346)$ & $(0.498)$ & $(0.346)$ & (0.399) & $(0.265)$ & $(0.670)$ \\
\hline \multirow[t]{2}{*}{ High ISCED } & $4.160 * * *$ & $3.293 * * *$ & $3.800 * * *$ & $4.524 * * *$ & $5.267^{* * *}$ & $2.538^{* * *}$ \\
\hline & $(0.355)$ & $(0.506)$ & $(0.355)$ & $(0.397)$ & $(0.256)$ & $(0.705)$ \\
\hline \multirow[t]{2}{*}{$2^{\text {nd }}$ Quarter } & -0.157 & 0.441 & 0.138 & 0.0254 & 0.0227 & 0.608 \\
\hline & $(0.225)$ & $(0.279)$ & $(0.217)$ & $(0.231)$ & $(0.143)$ & (0.409) \\
\hline \multirow[t]{2}{*}{ Constant } & $36.60 * * *$ & $39.01^{* * *}$ & $37.29 * * *$ & $37.57^{* * *}$ & $36.54 * * *$ & $36.57^{* * *}$ \\
\hline & $(0.603)$ & $(0.789)$ & $(0.593)$ & $(0.649)$ & $(0.395)$ & (1.154) \\
\hline Observations & 7,369 & 4,110 & 7,774 & 6,893 & 16,123 & 2,191 \\
\hline R-squared & 0.192 & 0.162 & 0.200 & 0.208 & 0.178 & 0.173 \\
\hline
\end{tabular}

When comparing the region of work specification (Table 9) to the region of residence specification (Table 10), note that the number of observations for Dublin in Table 10 is lower compared to Table 9. The opposite is the case for the other regions. This captures the fact that a lot of workers live outside Dublin but travel in to Dublin to work. If commuting workers are in some way different to individuals who live and work in the same location, then we may expect to see slight differences in the results from both specifications. For example, the hours effect in Dublin is greater in the region of residence specification compared to the region of work. The region of residence specification will not include the large number of workers from other regions who commute to Dublin to work. Given that commuters may invest a lot of time and money in travelling to work, they may be less likely to tolerate cuts to their hours compared to workers who live close to 
their job. These types of differences between workers with different regions of work and residence and workers who live and work in the same region, may explain why the results in Tables 9 and 10 are slightly different.

TABLE 10 DIFFERENCE-IN-DIFFERENCES ESTIMATES OF THE EFFECT OF MINIMUM WAGE CHANGE ON HOURS WORKED BY REGION OF RESIDENCE

\begin{tabular}{|c|c|c|c|c|c|c|}
\hline & (1) & (2) & (3) & (4) & (5) & (6) \\
\hline VARIABLES & $\begin{array}{c}\text { Border/ } \\
\text { Mid-East }\end{array}$ & West & $\begin{array}{l}\text { Mid-West/ } \\
\text { South East }\end{array}$ & South West & Dublin & Midland \\
\hline \multirow[t]{2}{*}{ DiD } & 0.318 & $-2.351^{* *}$ & $1.326^{*}$ & $1.446^{*}$ & $-2.052^{* * *}$ & $-2.544^{*}$ \\
\hline & $(0.701)$ & (0.991) & $(0.695)$ & $(0.803)$ & $(0.668)$ & (1.317) \\
\hline \multirow[t]{2}{*}{ Time } & 0.291 & 0.186 & 0.138 & 0.171 & 0.213 & $0.674^{*}$ \\
\hline & $(0.204)$ & $(0.285)$ & $(0.227)$ & $(0.241)$ & $(0.164)$ & $(0.377)$ \\
\hline \multirow[t]{2}{*}{ Minimum Wage } & $-9.067 * * *$ & $-6.465^{* * *}$ & $-9.187^{* * *}$ & $-8.848^{* * *}$ & $-8.995 * * *$ & $-8.509 * * *$ \\
\hline & $(0.531)$ & (0.743) & $(0.509)$ & $(0.581)$ & $(0.444)$ & $(0.975)$ \\
\hline \multirow[t]{2}{*}{ Age } & $-0.0200 * *$ & $-0.0632 * * *$ & $-0.0255^{* * *}$ & $-0.0380 * * *$ & $-0.0219 * * *$ & $-0.0520 * * *$ \\
\hline & $(0.00854)$ & $(0.0119)$ & $(0.00931)$ & (0.00995) & $(0.00668)$ & $(0.0162)$ \\
\hline \multirow[t]{2}{*}{ Female } & $-7.257^{* * *}$ & $-5.895 * * *$ & $-7.696^{* * *}$ & $-8.238^{* * *}$ & $-5.770 * * *$ & $-6.539 * * *$ \\
\hline & (0.199) & $(0.277)$ & $(0.217)$ & $(0.233)$ & $(0.156)$ & $(0.369)$ \\
\hline \multirow[t]{2}{*}{ Children (binary) } & $-0.499 * *$ & -0.299 & -0.0852 & $-0.819 * * *$ & $-0.798 * * *$ & 0.464 \\
\hline & $(0.200)$ & $(0.276)$ & $(0.218)$ & $(0.236)$ & $(0.161)$ & $(0.370)$ \\
\hline \multirow[t]{2}{*}{$\begin{array}{l}\text { Medium ISCED } \\
\text { (ref = low ISCED) }\end{array}$} & $2.477 * * *$ & $1.693 * * *$ & $1.924^{* * *}$ & $2.218^{* * *}$ & $2.078^{* * *}$ & 0.691 \\
\hline & $(0.318)$ & $(0.490)$ & $(0.340)$ & $(0.396)$ & $(0.285)$ & $(0.580)$ \\
\hline \multirow[t]{2}{*}{ High ISCED } & $4.303^{* * *}$ & $3.739 * * *$ & $3.508 * * *$ & $4.519 * * *$ & $5.828 * * *$ & $2.056 * * *$ \\
\hline & $(0.320)$ & $(0.498)$ & $(0.349)$ & $(0.394)$ & $(0.275)$ & $(0.606)$ \\
\hline \multirow[t]{2}{*}{$2^{\text {nd }}$ Quarter } & -0.215 & $0.689 * *$ & 0.206 & -0.0104 & 0.0167 & 0.145 \\
\hline & $(0.195)$ & $(0.271)$ & $(0.213)$ & $(0.230)$ & $(0.156)$ & $(0.360)$ \\
\hline \multirow[t]{2}{*}{ Constant } & $36.78^{* * *}$ & $37.98^{* * *}$ & $37.68 * * *$ & $37.80 * * *$ & $36.07 * * *$ & $39.13^{* * *}$ \\
\hline & $(0.536)$ & $(0.776)$ & $(0.585)$ & $(0.646)$ & $(0.423)$ & (1.009) \\
\hline Observations & 9,626 & 4,387 & 8,212 & 6,934 & 13,749 & 2,612 \\
\hline R-squared & 0.187 & 0.166 & 0.197 & 0.213 & 0.193 & 0.185 \\
\hline
\end{tabular}

Source: $\quad$ Irish Labour Force Survey 2017 and 2018.

Notes: $\quad$ The DiD model compares Q1/Q2 2017 with Q1/Q2 2018. Standard errors in parentheses with significance levels *** $\mathrm{p}<0.01, * * \mathrm{p}<0.05, * \mathrm{p}<0.1$.

When employing a DiD estimator, it is good practice to estimate the model on a time period during which no policy change occurred, a so-called 'placebo' time period. If significant effects were detected in the placebo time period, this may call into question the validity of the DiD estimator, as this may indicate that there were diverging trends between the treatment and control groups even before the policy change occurred; any statistically significant impact observed for the treatment period could simply be a product of such ongoing divergence. To verify the validity 
of our results and confirm that they are not being driven by diverging trends, we estimate our models using Quarters 1 and 2 of 2017 and Quarters 3 and 4 of 2017, during which time no minimum wage change occurred. Our ability to employ additional placebo tests on earlier time periods is constrained for two reasons. Firstly, the minimum wage question was added for the first time to the LFS in Quarter 2 of 2016. Secondly, we cannot use the period 2016 to 2017 as a placebo test, due to the minimum wage change which occurred in January 2017. Nevertheless, to the extent that trend effects will tend to be continuous over time, estimating our models for separate periods within a particular year during which the minimum wage was constant, is a reasonable robustness test.

The placebo results are shown in Tables 11 and 12 . We observe no statistically significant results in the Sector model (Table 11). Likewise, in the Region model (Table 12), we observe no statistically significant negative hours effect. There is a positive hours effect for the Midland region, however this is only marginally significant. This implies that our results for the treatment period are unlikely to be attributable to diverging trends. ${ }^{9}$ Therefore, we can rule this out as a factor explaining the observed changes in hours worked. Furthermore, given that our DiD models explicitly control for seasonality, we can also exclude this as a factor. The exclusion of both seasonal and trend explanations leads greater weight to the likelihood that the observed impacts were related to the 2018 minimum wage increase. 


\section{TABLE 11 DIFFERENCE-IN-DIFFERENCES PLACEBO ESTIMATES BY SECTOR}

\begin{tabular}{|c|c|c|c|c|}
\hline & (1) & (2) & (3) & (4) \\
\hline VARIABLES & $\begin{array}{c}\text { Wholesale and } \\
\text { Retail }\end{array}$ & $\begin{array}{l}\text { Accommodation } \\
\text { and Food }\end{array}$ & Manufacturing & Other \\
\hline \multirow[t]{2}{*}{ DiD } & 0.0500 & 0.164 & -0.772 & 0.647 \\
\hline & $(0.663)$ & $(0.834)$ & $(0.821)$ & $(0.517)$ \\
\hline \multirow[t]{2}{*}{ Time } & $-0.940 * * *$ & $-1.254^{* *}$ & $0.658 * *$ & 0.243 \\
\hline & (0.359) & $(0.580)$ & $(0.264)$ & $(0.156)$ \\
\hline \multirow[t]{2}{*}{ Minimum Wage } & $-9.158 * * *$ & $-8.054 * * *$ & $-2.689 * * *$ & $-7.546 * * *$ \\
\hline & $(0.478)$ & $(0.599)$ & $(0.599)$ & $(0.366)$ \\
\hline \multirow[t]{2}{*}{ Age } & $0.0826 * * *$ & $0.135^{* * *}$ & -0.0143 & $-0.0923 * * *$ \\
\hline & (0.0101) & $(0.0161)$ & (0.00873) & $(0.00478)$ \\
\hline \multirow[t]{2}{*}{ Female } & $-7.036 * * *$ & $-4.537 * * *$ & $-4.328 * * *$ & $-7.184 * * *$ \\
\hline & $(0.244)$ & $(0.380)$ & $(0.197)$ & $(0.112)$ \\
\hline \multirow[t]{2}{*}{ Children (binary) } & -0.102 & $-0.935^{* *}$ & $-0.637 * * *$ & $-1.032 * * *$ \\
\hline & $(0.246)$ & $(0.383)$ & $(0.185)$ & $(0.112)$ \\
\hline \multirow[t]{2}{*}{$\begin{array}{l}\text { Medium ISCED } \\
\text { (ref = low ISCED) }\end{array}$} & $3.198 * * *$ & $4.174 * * *$ & $0.802 * * *$ & $1.677^{* * *}$ \\
\hline & $(0.363)$ & $(0.547)$ & (0.299) & (0.198) \\
\hline \multirow[t]{2}{*}{ High ISCED } & $6.106 * * *$ & $8.629 * * *$ & $2.392 * * *$ & $3.683 * * *$ \\
\hline & (0.398) & $(0.599)$ & $(0.300)$ & (0.193) \\
\hline \multirow[t]{2}{*}{$2^{\text {nd }}$ Quarter } & -0.00611 & 0.447 & 0.0572 & $0.263^{*}$ \\
\hline & $(0.327)$ & $(0.504)$ & $(0.247)$ & $(0.145)$ \\
\hline \multirow[t]{2}{*}{$3^{\text {rd }}$ Quarter } & $0.963^{* * *}$ & $2.149 * * *$ & 0.252 & $0.356^{* *}$ \\
\hline & $(0.361)$ & $(0.559)$ & $(0.274)$ & $(0.166)$ \\
\hline \multirow[t]{2}{*}{ Constant } & $31.04 * * *$ & $25.78 * * *$ & $39.29 * * *$ & $40.57 * * *$ \\
\hline & $(0.625)$ & (0.949) & $(0.528)$ & $(0.313)$ \\
\hline Observations & 6,560 & 3,276 & 5,458 & 29,287 \\
\hline R-squared & 0.249 & 0.248 & 0.104 & 0.168 \\
\hline
\end{tabular}

Source: $\quad$ Irish Labour Force Survey 2017 and 2018.

Notes: $\quad$ The DiD model compares Q1/Q2 2017 with Q3/Q4 2017. Standard errors in parentheses with significance levels *** $p<0.01, * * p<0.05,{ }^{*} p<0.1$. 


\begin{tabular}{|c|c|c|c|c|c|c|}
\hline & (1) & (2) & (3) & (4) & (5) & (6) \\
\hline VARIABLES & $\begin{array}{l}\text { Border/ } \\
\text { Mid-East }\end{array}$ & West & $\begin{array}{l}\text { Mid-West/ } \\
\text { South East }\end{array}$ & South West & Dublin & Midland \\
\hline \multirow[t]{2}{*}{ DiD } & -0.1000 & -0.834 & -0.617 & -0.153 & -0.605 & $2.422 *$ \\
\hline & $(0.772)$ & $(1.046)$ & $(0.710)$ & $(0.789)$ & $(0.620)$ & (1.398) \\
\hline \multirow[t]{2}{*}{ Time } & 0.233 & $1.012 * *$ & -0.0196 & -0.245 & -0.0279 & $1.750 * * *$ \\
\hline & (0.329) & $(0.412)$ & $(0.316)$ & $(0.342)$ & $(0.207)$ & $(0.606)$ \\
\hline \multirow[t]{2}{*}{$\begin{array}{l}\text { Minimum } \\
\text { Wage }\end{array}$} & $-8.983 * * *$ & $-7.121 * * *$ & $-8.659 * * *$ & $-8.724 * * *$ & $-8.858 * * *$ & $-8.594 * * *$ \\
\hline & $(0.572)$ & $(0.782)$ & $(0.516)$ & $(0.566)$ & (0.429) & $(0.997)$ \\
\hline \multirow[t]{2}{*}{ Age } & $-0.0287^{* * *}$ & $-0.0713^{* * *}$ & $-0.0250 * * *$ & $-0.0347 * * *$ & $-0.0184 * * *$ & 0.0181 \\
\hline & $(0.00981)$ & $(0.0126)$ & $(0.00943)$ & $(0.0102)$ & $(0.00624)$ & $(0.0182)$ \\
\hline \multirow[t]{2}{*}{ Female } & $-7.266 * * *$ & $-5.490 * * *$ & $-7.614^{* * *}$ & $-8.430 * * *$ & $-6.028 * * *$ & $-6.073 * * *$ \\
\hline & $(0.236)$ & $(0.293)$ & $(0.223)$ & $(0.237)$ & $(0.143)$ & $(0.423)$ \\
\hline \multirow[t]{2}{*}{$\begin{array}{l}\text { Children } \\
\text { (binary) }\end{array}$} & $-0.480 * *$ & $-0.901 * * *$ & -0.0183 & $-1.021 * * *$ & $-0.955 * * *$ & 0.678 \\
\hline & $(0.237)$ & $(0.293)$ & $(0.223)$ & $(0.240)$ & $(0.146)$ & $(0.425)$ \\
\hline \multirow[t]{2}{*}{$\begin{array}{l}\text { Medium } \\
\text { ISCED (ref } \\
=\text { low } \\
\text { ISCED) }\end{array}$} & $2.500 * * *$ & 0.778 & $2.026 * * *$ & $2.199 * * *$ & $1.947^{* * *}$ & $1.879 * * *$ \\
\hline & $(0.352)$ & $(0.508)$ & $(0.347)$ & $(0.401)$ & $(0.265)$ & $(0.664)$ \\
\hline \multirow[t]{2}{*}{ High ISCED } & $4.100 * * *$ & $2.392 * * *$ & $3.779 * * *$ & $4.187^{* * *}$ & $5.318^{* * *}$ & $3.214 * * *$ \\
\hline & $(0.363)$ & $(0.513)$ & $(0.357)$ & (0.399) & $(0.256)$ & $(0.699)$ \\
\hline \multirow[t]{2}{*}{ Quarter 2} & 0.0736 & $0.728^{*}$ & 0.176 & 0.0507 & 0.155 & 0.843 \\
\hline & (0.319) & (0.389) & $(0.296)$ & (0.317) & (0.187) & $(0.555)$ \\
\hline \multirow[t]{2}{*}{ Quarter 3} & 0.392 & 0.349 & $0.584^{*}$ & $1.060 * * *$ & $0.712 * * *$ & -0.591 \\
\hline & $(0.335)$ & $(0.424)$ & $(0.320)$ & $(0.347)$ & $(0.221)$ & $(0.614)$ \\
\hline Constant & $\begin{array}{l}36.53^{* * *} \\
(0.625)\end{array}$ & $\begin{array}{l}39.30 * * * \\
(0.822)\end{array}$ & $\begin{array}{l}37.21 * * * \\
(0.600)\end{array}$ & $\begin{array}{c}37.77 * * * \\
(0.665)\end{array}$ & $\begin{array}{c}36.57 * * * \\
(0.399)\end{array}$ & $\begin{array}{c}33.93 * * * \\
(1.160)\end{array}$ \\
\hline Observations & 7,072 & 4,132 & 7,887 & 6,583 & 15,876 & 2,037 \\
\hline R-squared & 0.188 & 0.139 & 0.201 & 0.226 & 0.185 & 0.157 \\
\hline
\end{tabular}

Source: Irish Labour Force Survey 2017 and 2018.

Notes: $\quad$ The DiD model compares Q1/Q2 2017 with Q3/Q4 2017. Standard errors in parentheses with significance levels *** $p<0.01, * * p<0.05, * p<0.1$. Region of work used in the analysis.

While we observe changes in hours worked in some regions and in the manufacturing sector, the question of what exactly is driving these movements remains open. In theory, changes to hours following the rate rise could be due to behavioural responses of either employers or employees. ${ }^{10}$ Employers may respond by reducing the hours of existing employees, thereby explaining the hours reduction. An alternative explanation may be due to compositional effects of labour supply, if the minimum wage entices more part-time minimum wage

10 This could also be due to a combination of both employer and employee behavioural responses. 
employees into the labour market. To disentangle these two effects, we restrict our sample to incumbent employees who were with the same employer prior to the 2018 rate rise. If we observe that the impacts in hours worked were experienced by the incumbent sample, this would provide evidence against compositional effects.

In Tables 13 and 14, we re-estimate our DiD model on hours worked restricting our sample to individuals who began their current job before, or during, 2017. This ensures that only individuals who were in their job both before, and after, the 2018 rate rise are included in the data, thereby allowing us to measure the impact of the policy on the hours worked of incumbent employees only. The results are largely unchanged from those in Tables 8 and 9. Therefore, the changes in hours worked observed in our earlier models relate to impacts felt by existing employees, and not to compositional changes driven by flows of employees into, or out of, regions or sectors.

We next undertake a series of robustness tests, using our sample of incumbent employees. These include (i) dropping public sector employees from the sample on the grounds that many of these will also have received a pay increase in January 2018 and given the fact that MW employees do not typically work in the public sector, ${ }^{11}$ (ii) adding a marital dummy to the models, and (iii) adding firm size and occupational controls to the models. We also test for the persistence of impacts beyond the first quarter of 2018.

11 On January 1, 2018, public sector annualised salaries increased by 1 per cent as part of the Public Service Stability Agreement. 
TABLE 13

DIFFERENCE-IN-DIFFERENCES HOURS ESTIMATES BY SECTOR (CONDITIONAL ON STARTING THE JOB BEFORE 2018)

\begin{tabular}{|c|c|c|c|c|}
\hline & (1) & (2) & (3) & (4) \\
\hline VARIABLES & $\begin{array}{c}\text { Wholesale and } \\
\text { Retail }\end{array}$ & $\begin{array}{c}\text { Accommodation } \\
\text { and Food }\end{array}$ & Manufacturing & Other \\
\hline \multirow[t]{2}{*}{ DiD } & -0.715 & 0.199 & $-1.644 * *$ & 0.826 \\
\hline & (0.697) & $(0.869)$ & $(0.822)$ & $(0.536)$ \\
\hline \multirow[t]{2}{*}{ Time } & $-0.578 * *$ & -0.489 & $0.768 * * *$ & $0.406 * * *$ \\
\hline & $(0.277)$ & $(0.463)$ & $(0.186)$ & $(0.115)$ \\
\hline \multirow[t]{2}{*}{ Minimum Wage } & $-9.121 * * *$ & $-8.275 * * *$ & $-2.900 * * *$ & $-7.493 * * *$ \\
\hline & $(0.486)$ & (0.609) & $(0.578)$ & $(0.370)$ \\
\hline \multirow[t]{2}{*}{ Age } & $0.0834 * * *$ & $0.121^{* * *}$ & $-0.0223 * * *$ & $-0.101 * * *$ \\
\hline & (0.0106) & (0.0164) & $(0.00851)$ & $(0.00490)$ \\
\hline \multirow[t]{2}{*}{ Female } & $-6.889 * * *$ & $-4.040 * * *$ & $-4.094 * * *$ & $-7.299 * * *$ \\
\hline & $(0.253)$ & (0.393) & (0.193) & $(0.113)$ \\
\hline \multirow[t]{2}{*}{ Children (binary) } & 0.0757 & -0.414 & -0.209 & $-0.924 * * *$ \\
\hline & $(0.255)$ & $(0.397)$ & $(0.181)$ & $(0.113)$ \\
\hline \multirow[t]{2}{*}{$\begin{array}{l}\text { Medium ISCED } \\
\text { (ref =low ISCED) }\end{array}$} & $3.582 * * *$ & $3.863 * * *$ & $0.592 * *$ & $1.630 * * *$ \\
\hline & $(0.375)$ & (0.573) & $(0.296)$ & $(0.202)$ \\
\hline \multirow[t]{2}{*}{ High ISCED } & $6.632 * * *$ & $8.129 * * *$ & $2.026 * * *$ & $3.689 * * *$ \\
\hline & $(0.410)$ & $(0.620)$ & $(0.297)$ & (0.197) \\
\hline \multirow[t]{2}{*}{ Quarter 2} & -0.0283 & 0.380 & 0.188 & 0.110 \\
\hline & $(0.251)$ & $(0.388)$ & (0.179) & $(0.111)$ \\
\hline \multirow[t]{2}{*}{ Constant } & $30.48 * * *$ & $26.07 * * *$ & $39.50 * * *$ & $41.03 * * *$ \\
\hline & $(0.639)$ & $(0.960)$ & $(0.510)$ & $(0.316)$ \\
\hline Observations & 6,224 & 3,070 & 5,230 & 28,379 \\
\hline R-squared & 0.252 & 0.228 & 0.106 & 0.171 \\
\hline
\end{tabular}

Source: $\quad$ Irish Labour Force Survey 2017 and 2018.

Notes: $\quad$ The DiD model compares Q1/Q2 2017 with Q1/Q2 2018. Standard errors in parentheses with significance levels *** p<0.01, $* * p<0.05, * p<0.1$. 
TABLE 14

DIFFERENCE-IN-DIFFERENCES HOURS ESTIMATES BY REGION (CONDITIONAL ON STARTING THE JOB BEFORE 2018)

\begin{tabular}{|c|c|c|c|c|c|c|}
\hline & (1) & (2) & (3) & (4) & (5) & (6) \\
\hline VARIABLES & $\begin{array}{l}\text { Border/ } \\
\text { Mid-East }\end{array}$ & West & $\begin{array}{l}\text { Mid-West/ } \\
\text { South East }\end{array}$ & South West & Dublin & Midland \\
\hline \multirow[t]{2}{*}{ DiD } & -0.627 & $-1.939 *$ & 0.817 & 1.160 & $-1.576 * *$ & -1.563 \\
\hline & $(0.776)$ & $(1.044)$ & $(0.728)$ & $(0.828)$ & $(0.681)$ & $(1.456)$ \\
\hline \multirow[t]{2}{*}{ Time } & $0.472 *$ & 0.325 & 0.132 & $0.421 *$ & $0.412 * * *$ & $0.804 *$ \\
\hline & $(0.243)$ & (0.299) & $(0.236)$ & $(0.249)$ & $(0.155)$ & $(0.438)$ \\
\hline \multirow[t]{2}{*}{ Minimum Wage } & $-9.085^{* * *}$ & $-6.680 * * *$ & $-8.747 * * *$ & $-8.977 * * *$ & $-8.922 * * *$ & $-8.875 * * *$ \\
\hline & $(0.571)$ & $(0.772)$ & $(0.511)$ & $(0.578)$ & $(0.439)$ & $(1.041)$ \\
\hline \multirow[t]{2}{*}{ Age } & $-0.0325 * * *$ & $-0.0771 * * *$ & $-0.0273 * * *$ & $-0.0486 * * *$ & $-0.0241 * * *$ & $-0.0320^{*}$ \\
\hline & (0.00994) & (0.0125) & (0.00969) & $(0.0104)$ & $(0.00647)$ & $(0.0185)$ \\
\hline \multirow[t]{2}{*}{ Female } & $-7.328 * * *$ & $-5.615 * * *$ & $-7.732 * * *$ & $-8.129 * * *$ & $-5.999 * * *$ & $-6.441 * * *$ \\
\hline & $(0.236)$ & (0.291) & $(0.226)$ & $(0.240)$ & $(0.149)$ & $(0.427)$ \\
\hline \multirow[t]{2}{*}{ Children (binary) } & $-0.495 * *$ & $-0.647 * *$ & -0.125 & $-0.783 * * *$ & $-0.619 * * *$ & 0.435 \\
\hline & $(0.238)$ & $(0.289)$ & $(0.227)$ & $(0.243)$ & $(0.151)$ & $(0.429)$ \\
\hline \multirow[t]{2}{*}{$\begin{array}{l}\text { Medium ISCED } \\
\text { (ref =low ISCED) }\end{array}$} & $2.544 * * *$ & $1.468 * * *$ & $2.108 * * *$ & $2.036^{* * *}$ & $1.853^{* * *}$ & 0.866 \\
\hline & $(0.355)$ & $(0.505)$ & (0.354) & $(0.414)$ & $(0.274)$ & $(0.682)$ \\
\hline \multirow[t]{2}{*}{ High ISCED } & $4.045^{* * *}$ & $3.336 * * *$ & $3.732 * * *$ & $4.359 * * *$ & $5.176 * * *$ & $2.416 * * *$ \\
\hline & $(0.364)$ & (0.513) & $(0.363)$ & $(0.412)$ & $(0.264)$ & $(0.718)$ \\
\hline \multirow[t]{2}{*}{ Quarter 2} & -0.122 & 0.340 & 0.182 & 0.102 & 0.0920 & 0.609 \\
\hline & $(0.231)$ & $(0.284)$ & $(0.221)$ & $(0.237)$ & $(0.148)$ & $(0.417)$ \\
\hline \multirow[t]{2}{*}{ Constant } & $36.85^{* * *}$ & $38.93 * * *$ & $37.42 * * *$ & $38.04^{* * *}$ & $36.73 * * *$ & $37.27 * * *$ \\
\hline & $(0.618)$ & $(0.804)$ & (0.607) & $(0.674)$ & $(0.408)$ & $(1.180)$ \\
\hline Observations & 6,942 & 3,947 & 7,425 & 6,414 & 15,159 & 2,098 \\
\hline R-squared & 0.197 & 0.157 & 0.201 & 0.216 & 0.177 & 0.174 \\
\hline urce: & Survey 2017 & 2018. & & & & \\
\hline $\begin{array}{l}\text { The DiD m } \\
* * p<0.05 \text {, }\end{array}$ & ompares 2017 & Q2 with 2018 & 2. Standard e & & & $* * p<0.01$ \\
\hline
\end{tabular}

The results for the sectoral models are reported in Table A1 in the Appendix. The negative hours effect for manufacturing is robust to all specifications. In terms of the persistence of the sectoral impacts, when we estimate the model for Q2/Q3 2017 to Q2/Q3 2018, and Q3/Q4 2017 to Q3/Q4 2018, the coefficients are broadly similar. However, the impacts for the Q2/Q3 and Q3/Q4 models are either not statistically significant or only marginally significant. Therefore, we cannot be fully confident that the fall in hours worked among minimum wage employees in the manufacturing sector persisted into the second half of 2018.

Table A2 shows the results of the robustness tests for the regional models. The estimated impacts for Dublin and the West are robust to the alternative specifications. With respect to the West, the estimated hours effect is substantially 
larger when controls for occupation and firm size were added to the model. In terms of persistence, we detect no statistically significant regional hours effects for the Q3/Q4 models. Therefore, the fall in hours worked among minimum wage employees may not have persisted beyond the first six months of 2018. The lack of any strong evidence related to persistent impacts at the regional model is, perhaps, not surprising given the macroeconomic context of strong economic growth, falling unemployment and rising demand for labour. However, the fact that such regional variations existed at all leave open the possibility that the duration of adjustments could become more extensive in depressed labour markets. 



\section{SECTION 5}

\section{Summary and conclusion}

This study tests for impacts in the hours worked of MW employees following the 2018 rate change, which saw the minimum wage increase from €9.25 to €9.55 per hour. In addition to analysing the impact of the rate change at a national level, we also test for the possibility of heterogeneous impacts occurring at the level of both region and sector. The rationale for the approach is to investigate whether findings of impacts carried out at a national level mask heterogeneous impacts that are restricted to minimum wage employees located in particular regions or sectors.

Approximately 8 per cent of all workers in Ireland were in minimum wage employment in 2017 and 2018. However, our analysis has shown that the incidence varies substantially by area, from 5 per cent of total employees in Dublin to over 10 per cent in the Border/Mid-East, Mid-West/South East and the Midland regions. With respect to sector, 30 per cent of all employees in the accommodation and food sector earn the minimum wage or less. In wholesale and retail, the incidence is approximately 16 per cent. These two sectors alone account for approximately 55 per cent of all minimum wage employees in Ireland. The incidence of minimum wage employment among manufacturing employees is lower, at 5.4 per cent, with these workers accounting for 8 per cent of all minimum wage employees.

In addition to variations in the incidence, we also found heterogeneity in the typical profile of minimum wage employees across regions and sectors. Minimum wage employees in Dublin tend to be younger, better educated, work on temporary contracts and have lower tenure than most other regions. With regard to sector, the profile of minimum wage workers in manufacturing looks very different to minimum wage employees in other sectors. Minimum wage employees in the manufacturing sector are more likely to be older, work full-time and have permanent jobs. For such employees, minimum wage employment is likely to represent their career. Therefore, based on their profile, these employees are likely to be reliant on statutory minimum wage increases to boost their incomes.

Our results show that the $2018 \mathrm{MW}$ increase did not lead to any changes in the overall average hours worked of minimum wage employees, when looking at the full national sample. However, the research also demonstrates that such aggregate analysis can mask heterogeneous impacts that can occur at the regional or sectoral level. With respect to region, in the six months following the 2018 rate rise, average hours worked by minimum wage employees, relative to non-minimum wage employees, fell by 1.6 hours per week in Dublin and 1.7 hours per week in the West 
region. The sectoral models indicate that the average hours worked of minimum wage employees, relative to non-minimum wage employees, in the manufacturing sector fell by 1.6 hours per week in the six-month period following the rate rise. In order to ensure that the estimated impacts were not caused by ongoing diverging trends in the hours worked of minimum and non-minimum wage workers, we reestimated our models for the period Q1/Q2 2017 to Q3/Q4 2017, during which the $\mathrm{MW}$ was constant. If the observed results were due to diverging pre-treatment trends, then it is reasonable to expect these results to be evident during this 2017 placebo period. However, no negative hours impacts were detected at either the regional or sectoral level in the placebo period. Therefore, this suggests that the hours effects observed in the first half of 2018 were linked to the minimum wage increase, as opposed to diverging trends between high and low paid workers.

Our central results were robust to a series of alternative specifications, and our regional results were broadly consistent when we used region of residence as opposed to region of work. We also show that the impacts were felt principally by minimum wage employees who were in their job prior to the 2018 rate change. Therefore, the hours effects were not driven by compositional changes related to higher flows of part-time workers into certain sectors or regions following the minimum wage increase. However, our analysis suggests that the observed impacts for Dublin, the West and the manufacturing sector did not appear to persist into the second half of 2018. It is possible that the immediate negative impact on the hours of minimum wage employees in the West, Dublin, and in the manufacturing sector would have been subsequently eased because of the continued tightening of the Irish labour market throughout 2018. However, the finding of possible heterogeneous impacts arising from the minimum wage change suggests that the existence of such variations should be monitored, particularly given that any impacts could become more persistent during periods of lower economic growth.

While the results from the study point towards a causal influence between the 2018 rate change and the heterogeneous change in hours worked of MW employees, some caution is required both in terms of the interpretation of results and the potential policy implications. While our placebo tests indicate that our results are not due to diverging pre-treatment trends in hours worked between $\mathrm{MW}$ and non-MW workers, the number of placebo periods available to us is limited, meaning that we cannot definitively rule out diverging trends as a factor. Secondly, despite the fact that our analysis points towards the changes being felt predominantly by incumbent MW workers, we cannot be certain about the exact mechanisms that brought about these changes and, consequently, the implications for policy. It could be that some of the observed impacts were due to employers reducing the hours of $\mathrm{MW}$ employees following the rate rise in order to reduce labour costs. However, it could also be the case that employees chose to substitute 
more leisure for less work as a result of the rise in pay. The data at hand do not allow us to identify the potential behavioural responses that brought about the observed falls in hours worked. There is a need for greater insights into exactly how firms and employees behave following MW rate changes, so that policy can be properly informed. This is particularly the case in instances, such as those in the manufacturing sector, where impacts are observed among individuals who appear to be career MW employees. 



\section{REFERENCES}

Belman, D., P. Wolfson and K. Nawakitphaitoon (2015). 'Who is affected by the minimum wage?', Industrial Relations: A Journal of Economy and Society, 54 (4): 582-621.

Cengiz, D., A. Dube, A. Lindner and B. Zipperer (2018). 'The effect of minimum wages on low-wage jobs: Evidence from the United States using a bunching estimator', Centre for Economic Performance, Discussion Paper No. 1531.

Del Carpio, X., H. Nguyen, L. Pabon and L.C. Wang (2015). 'Do minimum wages affect employment? Evidence from the manufacturing sector in Indonesia', IZA Journal of Labor \& Development, 4 (1): 17.

Dickens, R., R. Riley and D. Wilkinson (2015). 'A re-examination of the impact of the UK National Minimum Wage on employment', Economica, 82 (328): 841-64.

Dube, A. (forthcoming). 'Minimum wages and the distribution of family incomes', American Economic Journal: Applied Economics.

Galán, S. and S. Puente (2015). 'Minimum wages: Do they really hurt young people?', The BE Journal of Economic Analysis \& Policy, 15 (1): 299-328.

Gilbert, A., E. Phimister and I. Theodossiou (2001). 'The potential impact of the minimum wage in rural areas', Regional Studies, 35 (8): 765-70.

Hoffman, S.D. (2016). 'Are the effects of minimum wage increases always small? A reanalysis of Sabia, Burkhauser and Hansen', ILR Review, 69 (2): 295-311.

Katz, L.F. and A.B. Krueger (1992). 'The Effect of the Minimum Wage on the Fast-Food Industry', Industrial and Labor Relations Review (October 1992), pp. 6-21

Liu, S., T.J. Hyclak and K. Regmi (2016). 'Impact of the minimum wage on youth labor markets', Labour, 30 (1): 18-37.

Logue, C. and T. Callan (2016). 'Low Pay, Minimum Wages and Household Incomes: Evidence for Ireland', Budget Perspectives 2017 (Paper 3). Dublin: Economic and Social Research Institute.

MaCurdy, T. (2015). 'How effective is the minimum wage at supporting the poor?', Journal of Political Economy, 123 (2): 497-545.

McGuinness, S. and P. Redmond (2018). 'Estimating the Effect of an Increase in the Minimum Wage on Hours Worked and Employment in Ireland', IZA DP No. 11632.

Meer, J. and J. West (2016). 'Effects of the minimum wage on employment dynamics', Journal of Human Resources, 51 (2): 500-22.

Redmond, P., S. McGuinness and B. Maître (2018). 'An examination of the labour market transitions of minimum wage workers in Ireland', Economic and Social Research Institute, Research Series Number 75. ESRI: Dublin.

Sabia J.J. and R.B. Nielsen (2015). 'Minimum wages, poverty, and material hardship: New evidence from the SIPP', Review of Economics of the Household, 13 (1): 95-134.

Sabia, J.J., R.V. Burkhauser and B. Hansen (2016). 'When good measurement goes wrong: New evidence that New York State's minimum wage reduced employment', ILR Review, 69 (2): 312-19. 
Schmitt, J. (2015). 'Explaining the small employment effects of the minimum wage in the United States', Industrial Relations: A Journal of Economy and Society, 54 (4): 54781.

Strobl, E. and F. Walsh (2016). 'Monopsony, minimum wages and migration', Labour Economics, Elsevier, Vol. 42(C), pp. 221-37.

Wang, W., P.C.B. Phillips and L. Su. (2019). 'The heterogeneous effects of the minimum wage on employment across states', Economics Letters, Elsevier, Vol. 174(C), pp. 179-85.

Williams, N. (1993). 'Regional effects of the minimum wage on teenage employment', Applied Economics, 25 (12): 1517-28.

Zavodny, M. (2000). 'The effect of the minimum wage on employment and hours', Labour Economics, 7 (6): 729-50. 


\section{APPENDIX}

TABLE A1 ROBUSTNESS CHECKS FOR SECTOR

\begin{tabular}{|c|c|c|c|c|}
\hline & $\begin{array}{l}\text { Wholesale } \\
\text { and Retail }\end{array}$ & $\begin{array}{c}\text { Accommodatio } \\
\mathbf{n} \text { and Food }\end{array}$ & Manufacturing & Other \\
\hline $\begin{array}{l}\text { Baseline (conditional on starting job } \\
\text { prior to 2018) }\end{array}$ & $\begin{array}{l}-0.715 \\
(0.697)\end{array}$ & $\begin{array}{c}0.199 \\
(0.869)\end{array}$ & $\begin{array}{l}-1.644 * * \\
(0.822)\end{array}$ & $\begin{array}{c}0.826 \\
(0.536)\end{array}$ \\
\hline \multicolumn{5}{|l|}{ Robustness Checks } \\
\hline $\begin{array}{l}\text { Drop public sector employees (N/A } \\
\text { for first } 3 \text { sectors as are mutually } \\
\text { exclusive) }\end{array}$ & $\begin{array}{l}-0.715 \\
(0.697)\end{array}$ & $\begin{array}{c}0.199 \\
(0.869)\end{array}$ & $\begin{array}{l}-1.644^{* *} \\
(0.822)\end{array}$ & $\begin{array}{c}0.365 \\
(0.553)\end{array}$ \\
\hline Add married dummy & $\begin{array}{l}-0.762 \\
(0.696)\end{array}$ & $\begin{array}{c}0.262 \\
(0.867)\end{array}$ & $\begin{array}{l}-1.644^{* *} \\
(0.822)\end{array}$ & $\begin{array}{c}0.821 \\
(0.536)\end{array}$ \\
\hline $\begin{array}{l}\text { Add firm size dummies and 1- digit } \\
\text { occupation dummies }\end{array}$ & $\begin{array}{l}-1.358^{* *} \\
(0.691)\end{array}$ & $\begin{array}{c}0.336 \\
(0.872)\end{array}$ & $\begin{array}{l}-2.243^{* * *} \\
(0.815)\end{array}$ & $\begin{array}{c}0.329 \\
(0.556)\end{array}$ \\
\hline $\begin{array}{l}\text { Compare Quarters } 2 \text { and } 3 \text { of } 2017 \\
\text { and } 2018\end{array}$ & $\begin{array}{c}0.314 \\
(0.766)\end{array}$ & $\begin{array}{l}-0.800 \\
(0.944)\end{array}$ & $\begin{array}{l}-1.439 \\
(0.930)\end{array}$ & $\begin{array}{c}0.239 \\
(0.588)\end{array}$ \\
\hline $\begin{array}{l}\text { Compare Quarters } 3 \text { and } 4 \text { of } 2017 \\
\text { and } 2018\end{array}$ & $\begin{array}{c}0.732 \\
(0.799)\end{array}$ & $\begin{array}{l}-0.132 \\
(1.024)\end{array}$ & $\begin{array}{l}-1.781^{*} \\
(0.994)\end{array}$ & $\begin{array}{l}1.675 * * * \\
(0.644)\end{array}$ \\
\hline
\end{tabular}

Source: $\quad$ Irish Labour Force Survey 2017 and 2018.

Notes: $\quad$ All robustness checks conditional on starting the job prior to 2018. Public sector employees refer to NACE sector 84 corresponding to 'Public administration and defence; compulsory social security'. Firm size takes on many categories denoting exact number of persons between one and ten, 11 to 19 persons, 20 to 49 persons, 50 to 99 persons, 100 to 249 persons, 250 to 500 persons, more than 500 persons. Ten one-digit occupation dummies were also added to the regression.

TABLE A2 ROBUSTNESS CHECKS FOR REGION

\begin{tabular}{|c|c|c|c|c|c|c|}
\hline & $\begin{array}{l}\text { Border/ } \\
\text { Mid-East }\end{array}$ & West & $\begin{array}{c}\text { Mid- } \\
\text { West/ } \\
\text { South East }\end{array}$ & $\begin{array}{l}\text { South } \\
\text { West }\end{array}$ & Dublin & Midland \\
\hline $\begin{array}{l}\text { Baseline (conditional on } \\
\text { starting job prior to } 2018 \text { ) }\end{array}$ & $\begin{array}{l}-0.627 \\
(0.776)\end{array}$ & $\begin{array}{l}-1.939 * \\
(1.044)\end{array}$ & $\begin{array}{c}0.817 \\
(0.728)\end{array}$ & $\begin{array}{c}1.160 \\
(0.828)\end{array}$ & $\begin{array}{l}-1.576 * * \\
(0.681)\end{array}$ & $\begin{array}{l}-1.563 \\
(1.456)\end{array}$ \\
\hline \multicolumn{7}{|l|}{ Robustness Checks } \\
\hline $\begin{array}{l}\text { Drop public sector } \\
\text { employees }\end{array}$ & $\begin{array}{l}-0.968 \\
(0.789)\end{array}$ & $\begin{array}{l}-1.913^{*} \\
(1.061)\end{array}$ & $\begin{array}{c}0.567 \\
(0.744)\end{array}$ & $\begin{array}{c}1.105 \\
(0.843)\end{array}$ & $\begin{array}{l}-1.732 * * \\
(0.691)\end{array}$ & $\begin{array}{l}-1.834 \\
(1.496)\end{array}$ \\
\hline Add married dummy & $\begin{array}{l}-0.662 \\
(0.776)\end{array}$ & $\begin{array}{l}-1.922^{*} \\
(1.044)\end{array}$ & $\begin{array}{c}0.836 \\
(0.728)\end{array}$ & $\begin{array}{c}1.157 \\
(0.828)\end{array}$ & $\begin{array}{l}-1.577^{* *} \\
(0.681)\end{array}$ & $\begin{array}{l}-1.549 \\
(1.455)\end{array}$ \\
\hline $\begin{array}{l}\text { Add firm size dummies } \\
\text { and 1- digit occupation } \\
\text { dummies }\end{array}$ & $\begin{array}{l}-1.592^{* *} \\
(0.785)\end{array}$ & $\begin{array}{l}-3.114^{* * *} \\
(1.068)\end{array}$ & $\begin{array}{c}0.318 \\
(0.725)\end{array}$ & $\begin{array}{c}0.565 \\
(0.843)\end{array}$ & $\begin{array}{l}-1.583^{* *} \\
(0.700)\end{array}$ & $\begin{array}{l}-2.033^{* *} \\
(1.488)\end{array}$ \\
\hline $\begin{array}{l}\text { Compare Quarters } 2 \text { and } 3 \\
\text { of } 2017 \text { and } 2018\end{array}$ & $\begin{array}{l}-0.980 \\
(0.849)\end{array}$ & $\begin{array}{l}-0.746 \\
(1.160)\end{array}$ & $\begin{array}{c}0.869 \\
(0.802)\end{array}$ & $\begin{array}{c}0.845 \\
(0.897)\end{array}$ & $\begin{array}{l}-1.664 * * \\
(0.776)\end{array}$ & $\begin{array}{l}-0.411 \\
(1.473)\end{array}$ \\
\hline $\begin{array}{l}\text { Compare Quarters } 3 \text { and } 4 \\
\text { of } 2017 \text { and } 2018\end{array}$ & $\begin{array}{c}1.335 \\
(0.880)\end{array}$ & $\begin{array}{l}-0.340 \\
(1.254)\end{array}$ & $\begin{array}{c}1.560^{*} \\
(0.875)\end{array}$ & $\begin{array}{l}2.471^{* *} \\
(0.973)\end{array}$ & $\begin{array}{c}0.185 \\
(0.845)\end{array}$ & $\begin{array}{l}-1.104 \\
(1.571)\end{array}$ \\
\hline
\end{tabular}

Source: Irish Labour Force Survey 2017 and 2018.

Notes: $\quad$ All robustness checks conditional on starting the job prior to 2018. Region refers to region of work. Public sector employees refer to NACE sector 84 corresponding to 'Public administration and defence; compulsory social security'. Firm size takes on many categories denoting exact number of persons between one and ten 11 to 19 persons, 20 to 49 persons, 50 to 99 persons, 100 to 249 persons, 250 to 500 persons, more than 500 persons. Ten one-digit occupation dummies were also added to the regression. 
TABLE A3 COUNTIES WITHIN NUTS 3 REGIONS IN 2018

\begin{tabular}{|c|c|c|c|}
\hline NUTS 3 REGION & Counties & NUTS 3 REGION & Counties \\
\hline \multirow[t]{6}{*}{ Border } & Donegal & South West & Cork \\
\hline & Sligo & & Kerry \\
\hline & Leitrim & & \\
\hline & Cavan & Dublin & Dublin \\
\hline & Monaghan & & \\
\hline & & Mid-East & Wicklow \\
\hline \multirow[t]{3}{*}{ West } & Galway & & Kildare \\
\hline & Mayo & & Meath \\
\hline & Roscommon & & Louth \\
\hline \multirow[t]{3}{*}{ Mid-West } & Clare & Midland & Longford \\
\hline & Tipperary & & Westmeath \\
\hline & Limerick & & Offaly \\
\hline \multirow[t]{4}{*}{ South East } & Waterford & & Laois \\
\hline & Kilkenny & & \\
\hline & Carlow & & \\
\hline & Wexford & & \\
\hline
\end{tabular}

TABLE A4 REGION CLASSIFICATION USED IN THE REPORT

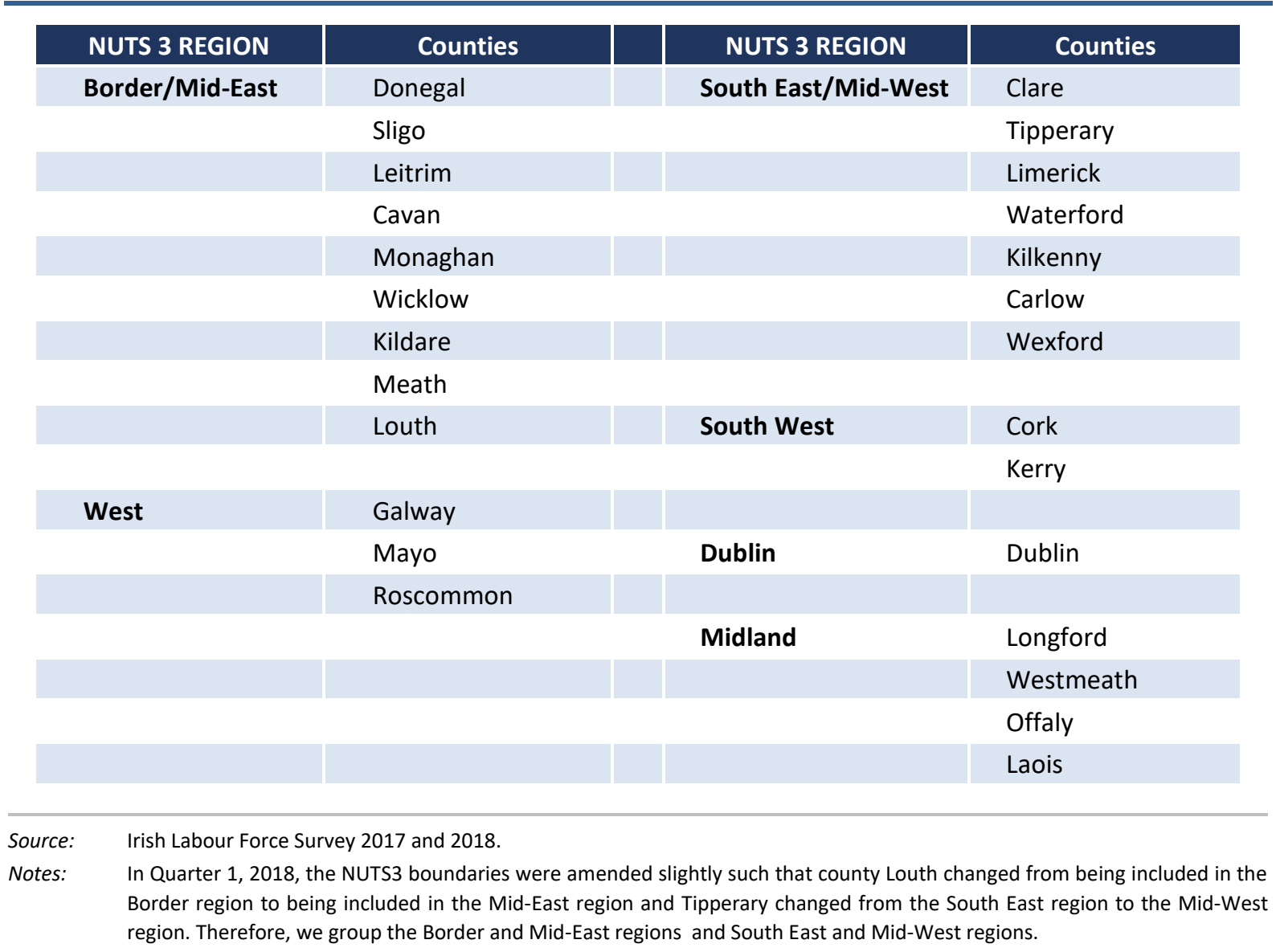


Whitaker Square,

Sir John Rogerson's Quay, Dublin 2

Telephone +35318632000

Email admin@esri.ie

Web www.esri.ie

Twitter @ESRIDublin

ISBN 978-0-7070-0502-7 